\title{
Evaluating the Effectiveness of Public Meetings and Workshops: A New Approach for Improving DOE Public Involvement
}

by $C$. Young, G. Williams, and M. Goldberg

Environmental Assessment and Iriformation Sciences Division, Argonne National Laboratory, 9700 South Cass Avenue, Argonne, Illinois 60439

July 1993

Work sponsored by United States Department of Energy, Assistant Secretary for Environmental Restoration and Waste Management
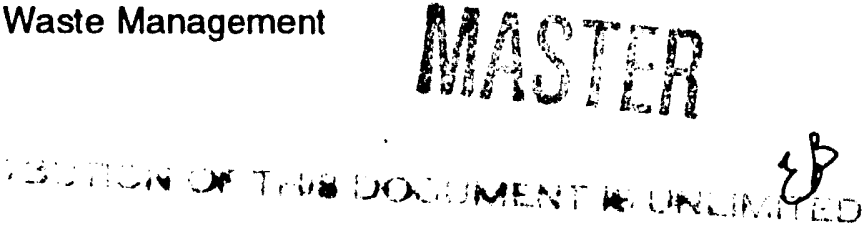


\section{CONTENTS}

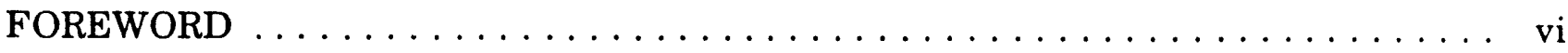

ACKNOWLEDGMENTS $\ldots \ldots \ldots \ldots \ldots \ldots \ldots \ldots \ldots \ldots \ldots \ldots \ldots \ldots \ldots$ vii

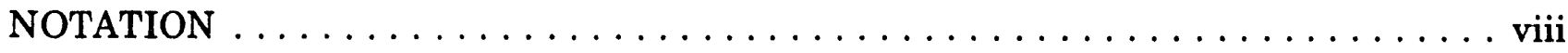





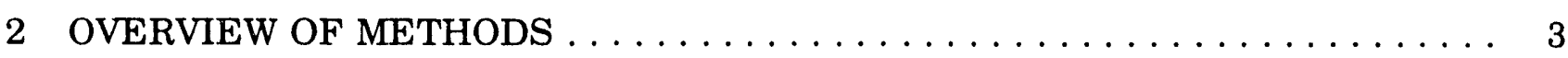

2.1 Components of Effectiveness $\ldots \ldots \ldots \ldots \ldots \ldots \ldots \ldots \ldots \ldots \ldots \ldots$



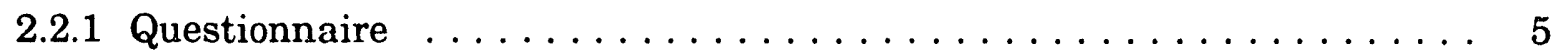

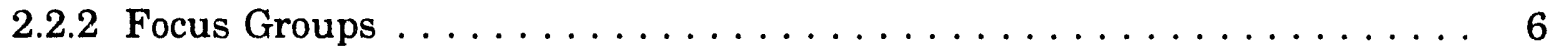

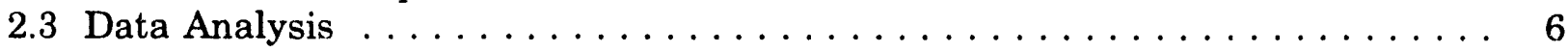

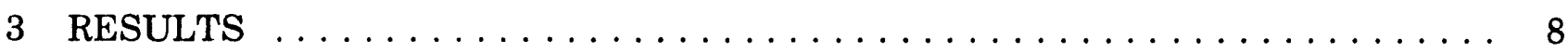

3.1 Description of Attendees $\ldots \ldots \ldots \ldots \ldots \ldots \ldots \ldots \ldots \ldots \ldots$

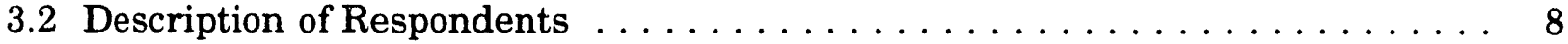

3.3 Components Related to Meeting Effectiveness ................... 14

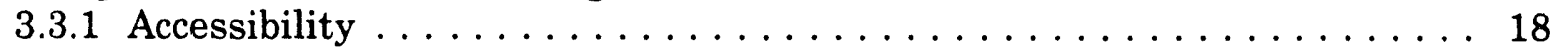

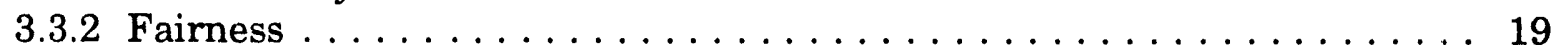

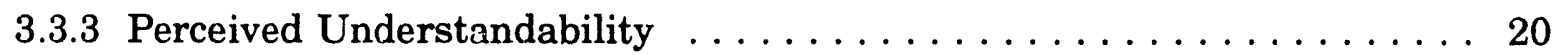

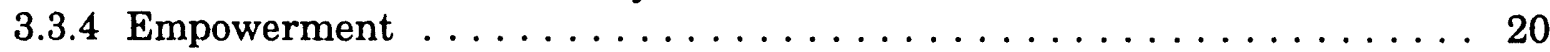

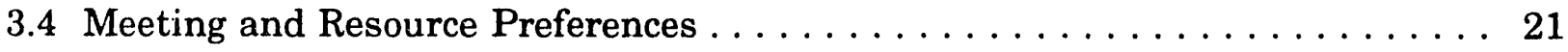

4 SUMMARY OF FINDINGS AND RECOMMENDATIONS $\ldots \ldots \ldots \ldots \ldots \ldots 24$

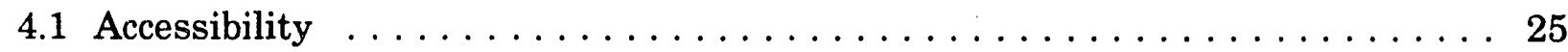

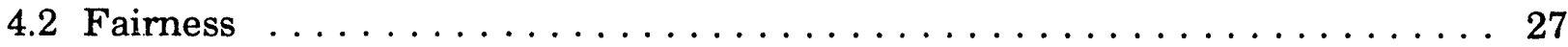

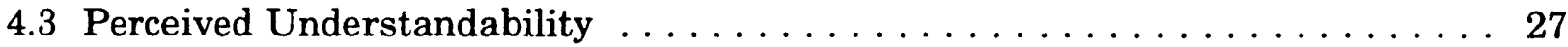

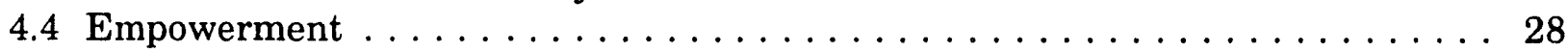

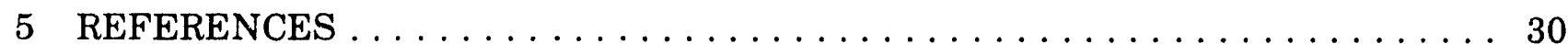

APPENDIX A: Questionnaires for the Workshops and Meetings .......... 31

APPENDIX B: Summary of DOE Questionnaire Responses and Focus

Group Findings ........................ 35

APPENDIX C: Summary of Public Focus Group Findings $\ldots \ldots \ldots \ldots \ldots \ldots$

APPENDIX D: Surveying Potential Attendees $\ldots \ldots \ldots \ldots \ldots \ldots \ldots \ldots$ 


\section{TABLES}

2.1 Characteristics of Implementation Plan Workshops and a

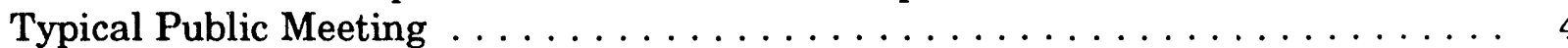

3.1 Numbers of Attendees by Organizational Affiliation for Each Meeting Location $\ldots \ldots \ldots \ldots \ldots \ldots \ldots \ldots \ldots \ldots \ldots \ldots$

3.2 Numbers of Respondents by Organizational Affiliation for Each

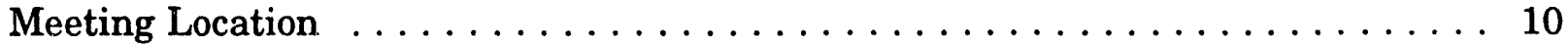

3.3 Respondents' Reasons for Attending DOE Implementation Plan

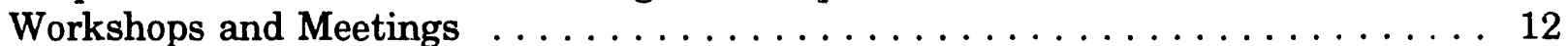

3.4 Respondents' Actions Taken during Workshops . . . . . . . . . . . . . . . . . 12

3.5 Respondents' Preferences for Having DOE Inform Them about

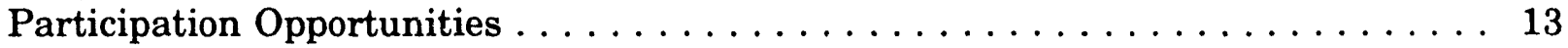

3.6 Types of Resources Respondents Would Like for Providing Input to DOE . . . . . 16

3.7 Questionnaire Items Covering Four Major

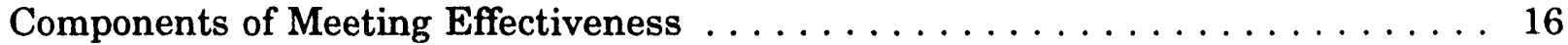

B.1 Tally of Findings from DOE Focus Groups for Major

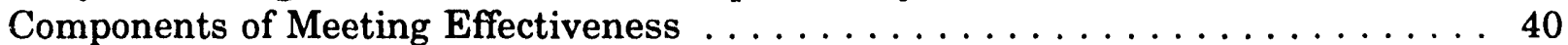

C.1 Tally of Findings from Public Focus Groups for Major

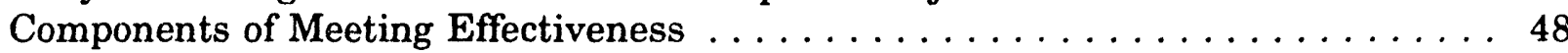

\section{FIGURES}

3.1 Non-DOE Respondents' Views of DOE on the Basis of Prior Experience . . . . . 13

3.2 Mean Responses Regarding Prior Experience with DOE, Segregated

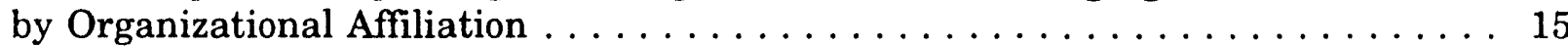

3.3 Mean Responses of Non-DOE Respondents on the Components of

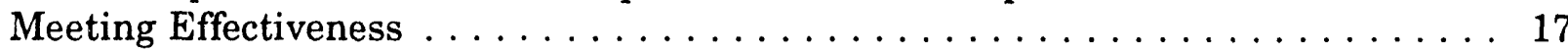

3.4 Non-DOE Respondents' Preferences for Characteristics of DOE Workshop . . . . 22

3.5 Non-DOE Respondents' Preferences for Information Sources to Increase Understanding of EM Topics . . . . . . . . . . . . . . . . . 23

A.1 Workshop Evaluation Questionnaire $\ldots \ldots \ldots \ldots \ldots \ldots \ldots \ldots \ldots$ 


\section{FIGURES (Cont.)}

A.2 Meeting Evaluation Questionnaire $\ldots \ldots \ldots \ldots \ldots \ldots \ldots \ldots \ldots \ldots$

B.1 Mean Responses of DOE Staff and Contractors on the Components of

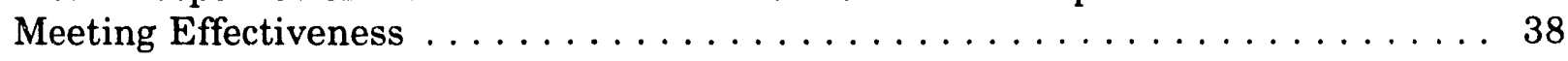

D.1 Mailout Questionnaire $\ldots \ldots \ldots \ldots \ldots \ldots \ldots \ldots \ldots \ldots \ldots \ldots \ldots$

D.2 Potential Attendees' Involvement with Premeeting Material

Accompanying the Mailout Questionnaire . . . . . . . . . . . . . 61

D.3 Potential Attendees' Perspectives on the Premeeting Materials ........... 61

D.4 Potential Attendees' Preferences for Providing Input to DOE $\ldots \ldots \ldots \ldots \ldots .62$

D.5 Potential Attendees' Ratings of the Importance of Resources for

Providing Input to DOE in the NEPA Process . . . . . . . . . . . . . 63 


\section{FOREWORD}

This report provicies the U.S. Department of Energy's (DOE's) Office of Environmental Restoration and Waste Management with suggestions for continuing to improve public involvement opportunities. Information contained in this report will also be useful for decision makers and program managers, in both public agencies and nonprofit groups, who are interested in increasing the effectiveness of their public involvement efforts. Recommendations are based on respondents' perspectives of the effectiveness of six workshops and meetings held as part of the review of the implementation plan for a programmatic environmental impact statement on policy alternatives for cleanup of DOE sites. 


\section{ACKNOWLEDGMENTS}

This effort was made possible by the vision of the U.S. Department of Energy's (DOE's) James Bauer (now at DOE's Richland Field Office), whose determination was appreciated by the authors and the puiblic who rated the "opportunity to evaluate the workshops/meetings" as one of the components of the meeting with which they were most satisfied. Remi Langum was an inspiration and provided many suggestions in the early stages of this project. Glen Sjoblom and James Melillo showed a devotion to improving public meetings and the flexibility to adapt the meeting structure in response to public needs and audience size. Barry Lawson and his team of impartial facilitators also were very helpful in providing insights into meeting effectiveness. 


\section{NOTATION}

The following is a list of the acronyms, initialisms, and abbreviations used in this document.
ANL Argonne National Laboratory
CEQ Council on Environmental Quality
DOE U.S. Department of Energy
EIS environmental impact statement
EM DOE's Office of Environmental Restoration and Waste Management
IP implementation plan (for the programmatic environmental impact statement)
NEPA National Environmental Policy Act
PEIS programmatic environmental impact statement
SPSS Statistical Package for the Social Sciences 


\title{
EVALUATING THE EFFECTIVENESS OF PUBLIC MEETINGS AND WORKSHOPS: A NEW APPROACH FOR IMPROVING DOE PUBLIC INVOLVEMENT
}

by

\author{
C. Young, G. Williams, and M. Goldberg
}

\begin{abstract}
Although public participation in the environmental cleanup process has been ongoing in the U.S. Department of Energy (DOE) for some time, little if any evaluation of these efforts to include the public has taken place. This report contains the results of an evaluation of six regional workshops and meetings. These meetings and workshops focused on the implementation plan for the programmatic environmental impact statement on DOE's environmental cleanup efforts. The formats of the workshops and meetings differed from typical public meetings by offering more opportunity for interaction between agency personnel and the public, using impartial facilitators, and including more elaborate promotional strategies than notification in the Federal Register. Questionnaires and focus groups were used to solicit participants' perspectives on the meetings. Participants indicated that they generally felt the meetings were fair and open. Furthermore, respondents indicated that the written materials and oral presentations were satisfactory, although the reading levels of some documents were corsidered inappropriately high. Participants also felt that they would have some impact on the decisions to be made. On the other hand, participants indicated that DOE's efforts regarding accessibility could be improved. Improvements could include (1) better promotion of meetings by notifying local communication networks and (2) more conveniently scheduled and located meetings. These findings suggest that DOE's future public participation activities should employ these interactive formats and that additional effort is needed to improve meeting accessibility.
\end{abstract}

\section{INTRODUCTION}

The Council on Environmental Quality's (CEQ's) Regulations for Implementing the Procedural Provisions of the National Environmental Policy Act (NEPA) requires that the public be involved as early as possible in the environmental assessment process and that public concerns be considered (CEQ 1986). This requirement is mirrored in the U.S. Department of Energy's (DOE's) own NEPA guidance (DOE 1992) and is further implemented in Departmental guidance documents on public participation (DOE 1991). The DOE Office 
of Environmental Restoration and Waste Management (EM) intends to solicit public input at key decision points in the NEPA process associated with programmatic decisions on the cleanup of DOE facilities.

Although EM has been increasingly active in the public involvement area, no systematic effort has assessed the effectiveness of its public involvement activities. As part of the NEPA compliance activity for EM, Argonne National Laboratory (ANL) was asked to evaluate six daytime workshops and evening meetings that were held as part of the review of the draft implementation plan (IP) for the programmatic environmental impact statement (PEIS). The results of the evaluation show the effectiveness of these six workshops and meetings and suggest ways to improve future meetings and other mechanisms for public involvement. The results also provide a baseline for measuring the effectiveness of future meetings; the one-page questionnaire presented in Appendix A can be easily modified for evaluating additional meetings.

This document briefly describes the methods used to evaluate the six meetings and workshops and provides a detailed discussion of the results of the evaluation. This report is organized into five sections followed by four appendixes. In Section 2, the conceptual framework that guided the evaluation and the data collection methods are described in greater detail. Section 3 presents the results of the data collection efforts. On the basis of these results, Section 4 provides a set of recommendations to assist EM in designing effective public involvement formats for use in the ongoing PEIS process. Section 5 presents full citations for all sources referenced in the text. The methods and findings described in this report apply directly to EM's effort to improve its public involvement initiatives; moreover, they also apply to DOE at large as well as to other agencies and groups interested in improving their public participation activities. 


\section{OVERVIEW OF METHODS}

This section is divided into three subsections. First, the components related to effectiveness and the scope of the project are described. Second, the data collection approach is discussed. Finally, the statistics used to examine the data are explained.

\subsection{COMPONENTS OF EFFECTIVENESS}

The objective of the evaluation was to assess the effectiveness of the IP daytime workshops and evening meetings, which were structured differently than typical public meetings as mechanisms for public participation (Table 2.1). The effectiveness of the workshops was measured in terms of the public's satisfaction with its involvement and was assessed in terms of four major components:

- Accessibility: respondents' assessments of their access to, or the availability of, decision makers and documents/reports;

- Fairness: respondents' views on the rules that guide the conduct of public involvement and whether these rules were followed in the IP workshops;

- Perceived understandability: the ability of respondents to understand DOE presentations and written materials and to determine the accuracy of the material presented; and

- Empowerment: respondents' perspectives on whether they have some impact on the decision-making process.

These four components are indicators of effective public involvement (Rosener 1978; Glass 1979; Hadden 1981; Gundry and Heberlein 1984; Kasperson 1986; Syme and Eaton 1989). Although these four concepts essentially describe the public's view of what constitutes effectiveness, they can be linked to three goals that reflect DOE's views on what constitutes effectiveness:

- The DOE goal to "contribute to public knowledge and understanding" is reflected in the concept of perceived understandability. This concept means that respondents felt they understood presentations and written materials.

- The goal to "obtain public input" is reflected in the respondents' feeling of empowerment. In other words, if participants feel empowered, it is likely that DOE obtained input from the public. 
TABLE 2.1 Characteristics of Implementation Plan Workshops and a Typical Public Meeting

\begin{tabular}{|c|c|c|}
\hline Characteristic or Format & $\begin{array}{l}\text { Implementation Plan } \\
\text { Workshops }\end{array}$ & Typical Public Meeting \\
\hline Group size & Small & Relatively large \\
\hline Type of interaction & Interactive dialogue & $\begin{array}{l}\text { One-way communication (public } \\
\text { to DOE); presentations by } \\
\text { individuals }\end{array}$ \\
\hline Amount of time to talk & More time to talk & Limited time to talk ( 5 minutes) \\
\hline $\begin{array}{l}\text { Presence of impartial } \\
\text { facilitator }\end{array}$ & Yes & Often \\
\hline Length & All day & All day/evening \\
\hline Type of topical discussion & $\begin{array}{l}\text { Designated topic within a } \\
\text { session }\end{array}$ & $\begin{array}{l}\text { Typically no discussion; } \\
\text { occasional questions and answers }\end{array}$ \\
\hline Orientation material & Yes, by mail and lecture & Yes, by lecture \\
\hline Visual aids & Graphics, posters & $\begin{array}{l}\text { Overhead transparencies } \\
\text { (occasionally) }\end{array}$ \\
\hline $\begin{array}{l}\text { Availability of technical } \\
\text { staff }\end{array}$ & $\begin{array}{l}\text { DOE provides technical } \\
\text { information and staff }\end{array}$ & $\begin{array}{l}\text { Programmatic staff may not be } \\
\text { technically familiar with subject }\end{array}$ \\
\hline Advance registration & $\begin{array}{l}\text { Preferred, but walk-ins } \\
\text { accepted }\end{array}$ & Preferred, but walk-ins accepted \\
\hline Record of events & $\begin{array}{l}\text { Notetakers paraphrasing and } \\
\text { summarizing discussion; DOE } \\
\text { reads summary of issues at } \\
\text { end of meeting }\end{array}$ & Court reporter, official transcript \\
\hline Next steps & $\begin{array}{l}\text { DOE summary of next-step } \\
\text { action items }\end{array}$ & No commitment to future action \\
\hline Promotional approaches & $\begin{array}{l}\text { Through letters, loc,al } \\
\text { newspapers, telephone calls, } \\
\text { Federal Register }\end{array}$ & $\begin{array}{l}\text { Through Federal Register, local } \\
\text { newspapers }\end{array}$ \\
\hline Session atmosphere & Encourages dialogue & $\begin{array}{l}\text { Fosters presenting a position for } \\
\text { public record }\end{array}$ \\
\hline Breakout sessions & $\begin{array}{l}\text { Four technical breakout } \\
\text { sessions; question and answer } \\
\text { period; summary session }\end{array}$ & No breakout sessions \\
\hline $\begin{array}{l}\text { Evaluation of } \\
\text { effectiveness }\end{array}$ & $\begin{array}{l}\text { Questionnaire and focus } \\
\text { groups }\end{array}$ & None or ad hoc \\
\hline
\end{tabular}


- Finally, the goal to "create an atmosphere to build public trust and confidence (by providing a visible, equitable, and legitimate process for decision making)" is linked to the public's views of fairness and accessibility. In essence, this means that if participants feel the process is fair and accessible, DOE will be approaching its goal of providing an atmosphere for building trust and confidence.

In addition to participants' perspectives on the four major components of effectiveness, DOE was interested in answering several other questions about the meetings and workshops that would contribute to improving participation:

- Who were respondents, and why were they attending the meetings?

- Did respondents from different organizational affiliations have different views on meeting effectiveness?

- Did respondents at different locations have different perspectives on meeting effectiveness?

- Did evaluations by the daytime workshop respondents differ from those of respondents at the evening meetings?

- What preferences did respondents have for how meetings are structured, and what did they need to improve their ability to participate?

The techniques used to gather data to answer these questions are discussed as follows.

\subsection{DATA COLLECTION}

Information on the four components of effectiveness and information necessary to answer each question above was collected by means of questionnaires and focus groups at each workshop and meeting.

\subsubsection{Questionnaire}

A questionnaire was used at the daytime workshops and evening meetings (Appendix A). Questionnaires were chosen as a data collection tool because they allow responses to be compared across participants and are a relatively simple way for respondents to react to material on meeting and workshop effectiveness (as opposed to describing or explaining it) (Ertel 1979). ${ }^{1}$ The one-page format contained five blocks of questions that

1 Two separate but similar questionnaires were used for the workshops and meetings. A longer version of the questionnaire was reviewed by the National Opinion Research Center at the University of Chicago and pretested on a sample of informed people before being used at the meetings. 
addressed (1) meeting effectiveness (accessibility, fairness, perceived understandability, and empowerment); (2) desirable characteristics of workshops or meetings; (3) prior experience with DOE; (4) helpful sources of information; and (5) background questions, such as reasons for attending the meeting or workshop. At all six meeting locations, the questionnaire was distributed at the last workshop session or at the close of the meeting. All attendees (including DOE participants) were asked to complete this questionnaire.

\subsubsection{Focus Groups}

Additional qualitative information relating to the four components of effectiveness was obtained from focus groups. The focus group format was chosen because it is particularly suited to capturing broad themes about a given topic and is an effective mechanism for obtaining in-depth information on preferences, perceptions, and attitudes (Desvousges and Smith 1988). Information from the focus groups was intended to be used in conjunction with the questionnaire results to provide detail and a context for the questionnaire responses. Participation in the focus group was obtained by asking for two volunteers from each of four sessions held during the day. The focus groups were held for 40-45 minutes after the cr.mpletion of the breakout sessions but before the final plenary session of the workshop. ${ }^{2}$ The focus group protocol was developed in conjunction with DOE to meet the logistical constraints of the meeting. ANL staff acted as facilitators and notetakers during the focus groups. DOE staff did not participate in these focus groups; separate focus groups were conducted specifically for DOE staff at each meeting site (DOE-specific results are discussed in Appendix B).

Participants in the focus groups were asked to identify important topics and rank order them relative to five predetermined topics. The topics were accessibility of DOE, fairness of the public involvement process, perceived understandability of DOE documents and presentations, impact of the public's comments on DOE, and ways to improve public involvement activities.

\subsection{DATA ANALYSIS}

Questionnaire data were analyzed with the Statistical Package for the Social Sciences (SPSS) with both descriptive and inferential statistics. Descriptive statistics were used to calculate mean responses for the indicators representing the four components related to meeting effectiveness (accessibility, fairness, perceived understandability, and empowerment) as well as for several other factors on which information was collected. Inferential statistical tests (student's $t$, one-way analysis of variance) were performed to examine differences in the respondents' mean responses on the four components of meeting effectiveness across meeting locations, across group types attending the meetings, and

2 The exception to this procedure was the Las Vegas meeting, where the last workshop session was combined with the focus group. 
bftween the daytime workshops and evening meetings. These tests are designed to investigate statistical differences in mean responses across various subsets of respondents, such as respondents from different locations. The 0.05 probability level was the cutoff point for determining statistical significance (i.e., if a statistical difference is identified, a $5 \%$ probability exists that the difference is due only to chance).

Data from the focus groups also were examined within the framework of the major components of meeting effectiveness (accessibility, fairness, perceived understandability, and empowerment). Focus group findings were integrated with the results of the questionnaires. Summaries of focus group issues, by city, for public participants are found in Appendix C. Issues and concerns of the DOE focus groups, as well as the results of the questionnaires completed by DOE staff, are summarized in Appendix B. 


\section{RESULTS}

This discussion of the results of the evaluation is organized into four major subsections. The first subsection describes the people who attended the meetings. The second subsection focuses on a description of the subset of people who responded to the questionnaire (called respondents for the remainder of this report). The third subsection provides respondents' perspectives on the four components that constitute meeting effectiveness. The fourth subsection discusses respondents' preferences for meeting formats and the resources they felt they needed to participate.

\subsection{DESCRIPTION OF ATTENDEES}

A total of 295 people attended the meetings and workshops. The numbers of attendees differed across locations and organizational affiliation (Table 3.1). DOE planned for approximately 60 participants at each workshop during the day and 50 people at each evening session. The total attendance at the six sessions (day and evening) was about half the initial expectations; the daytime workshop sessions were better attended than the evening sessions, but attendance was still lower than anticipated. The highest attendance was at the Washington, D.C., meeting, followed by Cincinnati; Atlanta had the lowest participation. The largest single group at the Washington meeting was DOE and its contractors, whereas environmental groups were the largest component in Atlanta and Cincinnati. In Las Vegas, participants with no particular affiliation were most numerous.

\subsection{DESCRIPTION OF RESPONDENTS}

All 295 attendees at the meetings and workshops were given questionnaires; 164 completed questionnaires. Overall, about $13 \%$ of the questionnaire respondents represented non-DOE federal, state, and local agencies; about $18 \%$ represented DOE and its contractors; approximately $18 \%$ were business people or consultants; $13 \%$ repre. ated environmental groups; and just over $38 \%$ had no affiliation listed (public/other). The distribution of respondents by group affiliation differed somewhat from city to city (Table 3.2). The low response for Washington was because few DOE attendees returned their questionnaires. The response rate for all non-DOE attendees was $63 \%$ (compared to the $56 \%$ overall response rate, which includes DOE-related attendees). The following discussion describes the findings for all respondents except the $29 \mathrm{DOE}$ staff and contractors who responded. Information on the responses of DOE staff and contractors is found in Appendix B. Some of these DOE attendees also participated in the focus group discussions.

The questionnaire results for non-DOE respondents indicated that they came from various locations and for diverse reasons. They were most likely to live 9 miles from a DOE facility. Several open-ended questions were used to ask respondents' reasons for attending, what they did at the workshops or meetings, preferences for information channels for future 


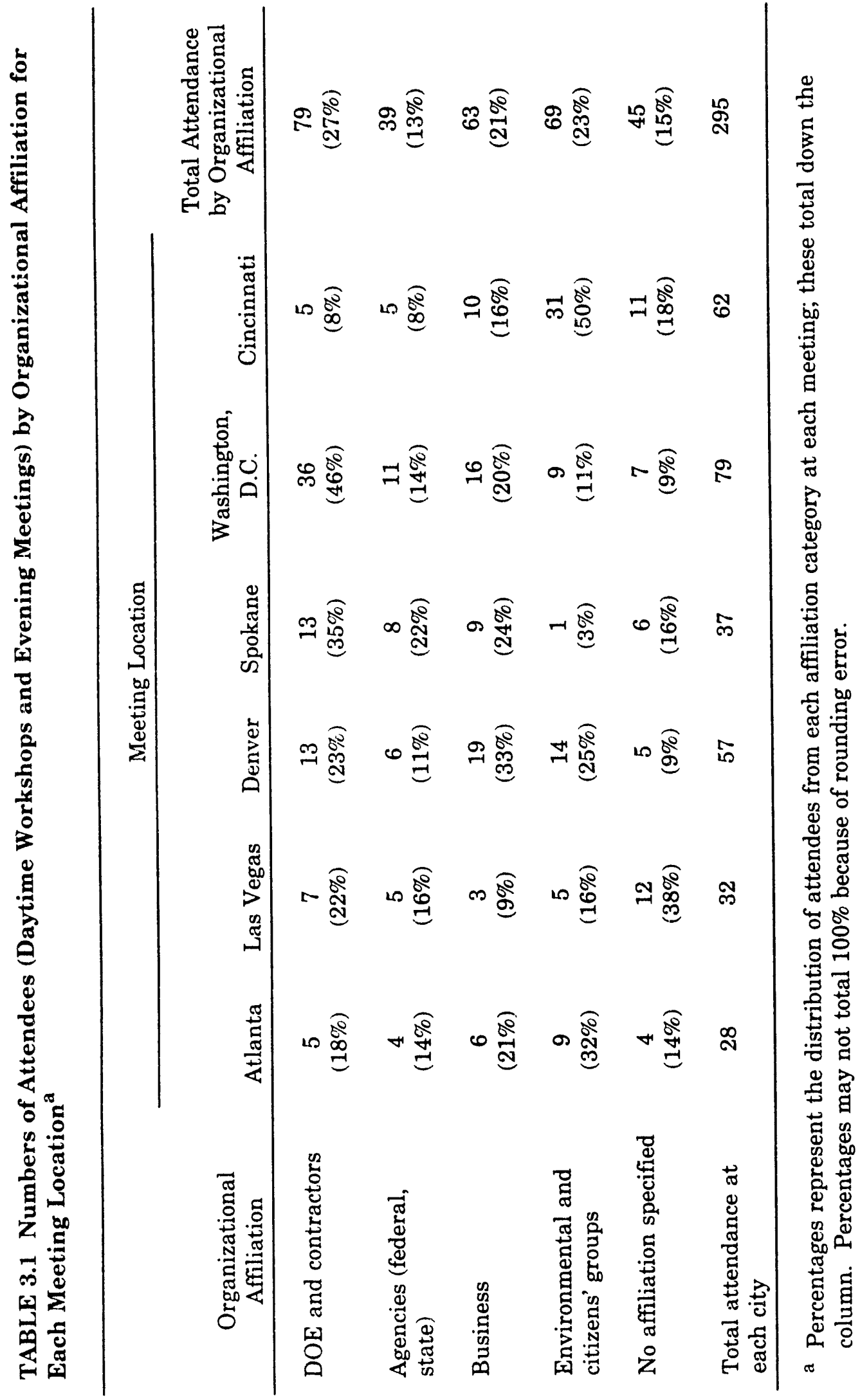




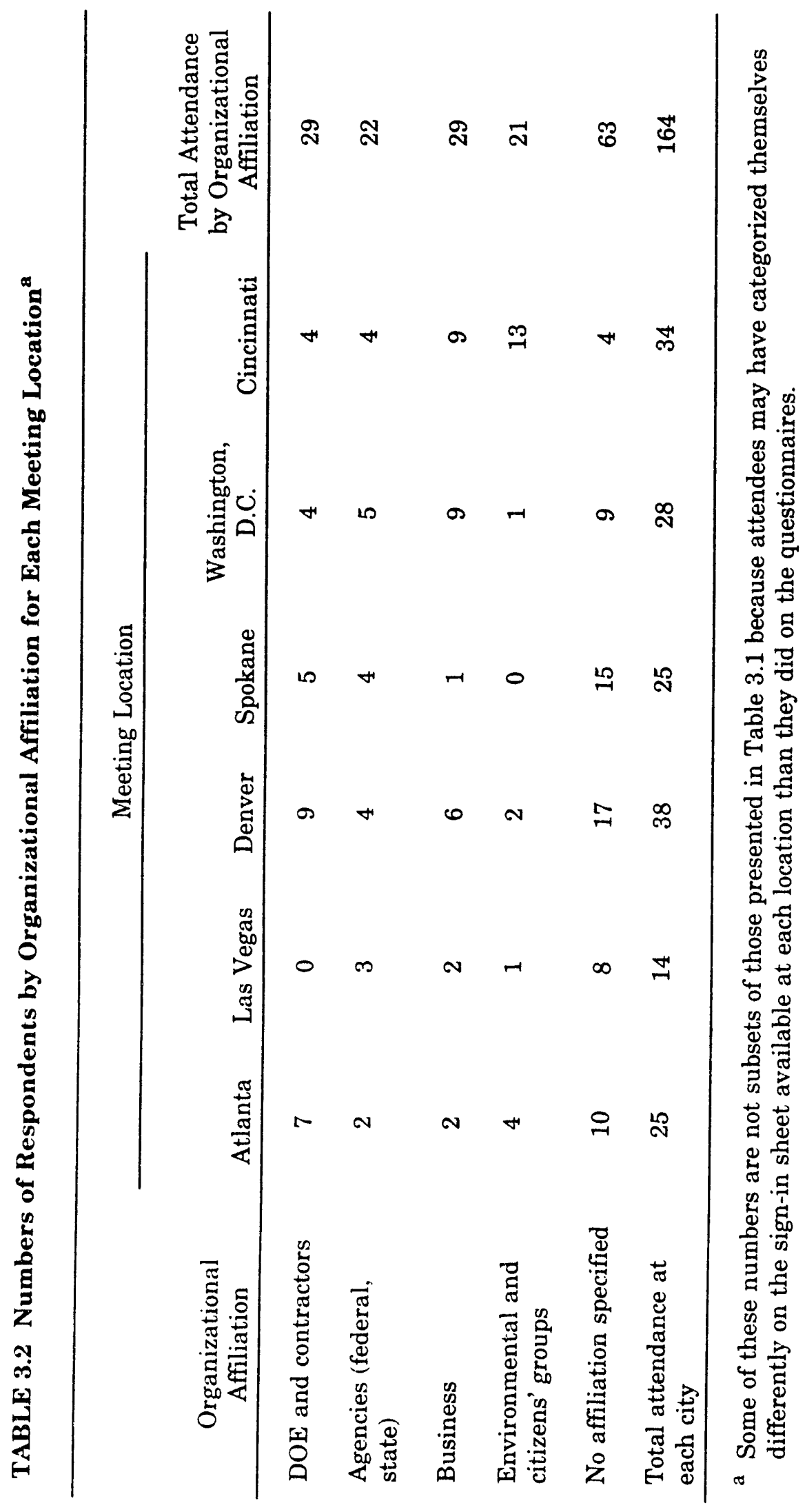


participation, and what they accomplished. ${ }^{3}$ Nearly one-quarter (22\%) of respondents attended the meetings to "learn more about the EM program" (Table 3.3). Although 19\% of the sample provided no reason for attending, others identified such reasons as to "participate in an organized show of concern" (8\%) and to "participate in the public involvement process" (4\%) (Table 3.3). "Other" reasons for attending ranged from general concern over nuclear problems and environmental issues to "required as part of the job." While space on the questionnaire was provided to list additional reasons for attending, more than $90 \%$ did not indicate a second reason.

Respondents also were involved in various activities during the workshops (Table 3.4). Of the sample, $25 \%$ spoke to DOE representatives; $16 \%$ attended technical breakout sessions, although $5 \%$ of respondents indicated that they only listened to presentations. It is likely that a number of respondents did not specifically list attending the workshops as an action, because $16 \%$ of the sample indicating such is lower than the number of respondents who actually attended the workshops. In fact, more than one-quarter of respondents did not specify what they did at the workshops.

Respondents also had preferences about how DOE should inform them of future participation opportunities (Table 3.5). Nearly half (45\%) of respondents indicated they preferred a letter from DOE. ${ }^{4}$ DOE seemed to anticipate this preference; it sent approximately 2,800 letters to people who attended previous scoping meetings, inviting them to this set of meetings. ${ }^{5}$ Interestingly, only a few respondents preferred Federal Register, radio, or personal contacts with $\mathrm{DOE}$ as ways of being notified about future participation opportunities.

Respondents were asked about their attitude toward DOE on the basis of prior experience (Figure 3.1). In general, respondents felt that DOE was quite willing to provide information and was somewhat accessible. However, respondents also thought that DOE was only somewhat credible and considerate of the public in making its decisions. Ranking lowest was DOE's objectivity in the decision-making process.

A series of analyses was performed to examine whether various groups (DOE, environmental groups, other state and federal agencies, business representatives/contractors, and those with no organizational affiliation) had differing attitudes toward DOE. Only environmental groups differed significantly from DOE in regard to prior experience with DOE

3 Open-ended questions require more effort from the respondent, so many respondents left these questions blank. Hence, the results were skewed toward those highly motivated attendees who wrote in responses.

4 This result should be interpreted within the context that potential attendees actually received letters of invitation from DOE. This may have prompted them to think of the letter option as a response.

5 Results from these "potential attendees" are discussed in Appendix D. 
TABLE 3.3 Respondents' Reasons for Attending DOE Implementation Plan Workshops and Meetings

\begin{tabular}{|c|c|c|c|c|}
\hline \multirow[b]{2}{*}{ Reason } & \multicolumn{2}{|c|}{ First Reason } & \multicolumn{2}{|c|}{ Second Reason } \\
\hline & Number & Percentage & Number & Percentage \\
\hline $\begin{array}{l}\text { Learn more about the EM } \\
\text { program }\end{array}$ & 30 & 22.2 & 3 & 2.2 \\
\hline No reason given (missing) & 25 & 18.5 & 124 & 91.9 \\
\hline $\begin{array}{l}\text { Participate in an organized show } \\
\text { of concern }\end{array}$ & 11 & 8.1 & 2 & 1.5 \\
\hline Demonstrate my concern to DOE & 6 & 4.4 & 2 & 1.5 \\
\hline $\begin{array}{l}\text { Participate in involvement } \\
\text { process }\end{array}$ & 5 & 3.7 & 0 & 0 \\
\hline Represent my group/organization & 2 & 1.5 & 0 & 0 \\
\hline Demonstrate my support to $\mathrm{DOE}$ & 1 & 0.7 & 0 & 0 \\
\hline Influence DOE decision making & 1 & 0.7 & 0 & 0 \\
\hline Other & 54 & 40.0 & 4 & 3 \\
\hline
\end{tabular}

TABLE 3.4 Respondents' Actions Taken during Workshops

\begin{tabular}{|c|c|c|c|c|}
\hline \multirow[b]{2}{*}{ Action } & \multicolumn{2}{|c|}{ First Action } & \multicolumn{2}{|c|}{ Second Action } \\
\hline & Number & Percentage & Number & Percentage \\
\hline No action specified (missing) & 37 & 27.4 & 116 & 85.0 \\
\hline Spoke to DOE representatives & 34 & 25.2 & 1 & 0.7 \\
\hline $\begin{array}{l}\text { Attended technical breakout } \\
\text { sessions }\end{array}$ & 22 & 16.3 & 0 & 0 \\
\hline Attended morning presentation & 7 & 5.2 & 0 & 0 \\
\hline Listened only & 7 & 5.2 & 2 & 1.5 \\
\hline $\begin{array}{l}\text { Learned something new about } \\
\text { DOE }\end{array}$ & 3 & 2.2 & 0 & 0 \\
\hline $\begin{array}{l}\text { Increased knowledge of EM } \\
\text { topics }\end{array}$ & 1 & 0.7 & 1 & 0.7 \\
\hline $\begin{array}{l}\text { Made contact with organized } \\
\text { group }\end{array}$ & 1 & 0.7 & 0 & 0 \\
\hline $\begin{array}{l}\text { Talked with other meeting } \\
\text { attendees }\end{array}$ & 0 & 0 & 1 & 0.7 \\
\hline Participated in focus group & 0 & 0 & 3 & 2.2 \\
\hline Other & 23 & 17.0 & 11 & 8.1 \\
\hline
\end{tabular}


TABLE 3.5 Respondents' Preferences for Having DOE Inform Them about Participation Opportunities

\begin{tabular}{lcccccc}
\hline & \multicolumn{2}{c}{ First Preference } & & \multicolumn{2}{c}{ Second Preference } \\
\cline { 2 - 3 } \cline { 5 - 6 } \multicolumn{1}{c}{ Method of Informing } & Number & Percentage & & Number & Percentage \\
\hline Letter from DOE & 61 & 45.2 & & 11 & 8.1 \\
No response (missing) & 27 & 20.0 & & 95 & 70.4 \\
Newspaper & 16 & 11.9 & & 13 & 9.6 \\
All methods & 14 & 10.4 & & 0 & 0 \\
Federal Register & 5 & 3.7 & & 1 & 0.7 \\
Radio & 1 & 0.7 & & 1 & 0.7 \\
Personal contact with DOE & 1 & 0.7 & & 0 & 0 \\
Television & 0 & 0 & & 3 & 2.2 \\
Communication with & 0 & 0 & & & \\
$\quad$ environmental group & & & & & & 0.7 \\
Other methods & 10 & 7.4 & & 10 & 7.4 \\
\hline
\end{tabular}

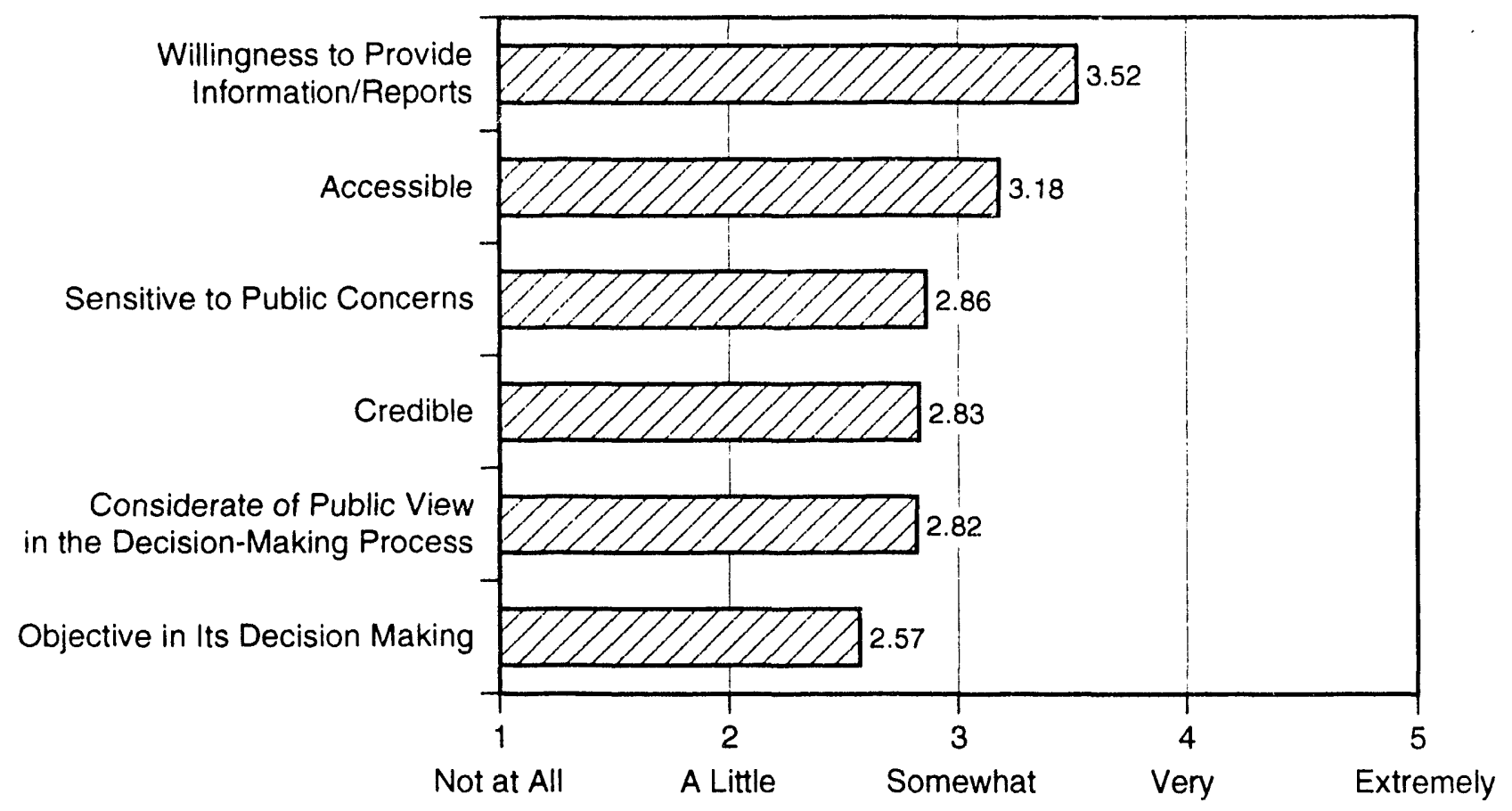

FIGURE 3.1 Non-DOE Respondents' Views of DOE on the Basis of Prior Experience 
(Figure 3.2). In particular, environmental group respondents were more negative than DOE in their evaluation of DOE's credibility, objectivity in its decision making, willingness to provide information/reports, and consideration of public views in the decision-making process. Interestingly, other groups, such as business representatives, held views similar (i.e., not statistically different) to those of DOE respondents on DOE's credibility, accessibility, objectivity in decision making, sensitivity to public concerns, willingness to provide information, and consideration of the public's view in the decision-making process. The reason for this lack of difference could be the relationship of the business representatives to DOE. Many seemed to be contr actors or people interested in working for DOE.

Respondents were asked what resources would help them provide input to DOE in the NEPA process. Nearly half of the respondents (45\%) listed nothing in response to this question (Table 3.6). The largest number identified "information on specific issues" (14\%), followed closely by "personal attention" (11\%), as helpful resources. Less than one-tenth of respondents mentioned other resource options such as "choice of meeting times" and "conveniently located meetings." Although space was provided for additional comments, nearly $90 \%$ of respondents did not list a second preferred resource.

\subsection{COMPONENTS RELATED TO MEETING EFFECTIVENESS}

The previous section provides basic descriptions of respondent characteristics; however, findings from those data do not specifically address respondents' perspectives on meeting effectiveness. The following four subsections describe the results from the questionnaire and focus group discussions specifically related to the four major components

of meeting effectiveness: accessibility, fairness, perceived understandability, and empowerment for all respondents except DOE personnel or DOE contractors. Responses for DOE personnel and DOE contractors are discussed separately in Appendix B. The results are organized around the questionnaire items related to each concept (Table 3.7 and Figure 3.3).

Several sets of analyses were conducted to examine the similarities and differences among the mean responses to questionnaire items related to the four components of effectiveness. A series of analyses (one-way analysis of variance) was performed to examine similarities and differences for the various subgroups attending the sessions: non-DOE agencies, DOE personnel/contractors, environmental groups, business people, and those with no organizational affiliation. No differences were found among these subgroups in terms of the four components of effectiveness. Another series of analyses using one-way analysis of variance was performed to investigate similarities and differences across meeting locations (Atlanta, Las Vegas, Spokane, Denver, Washington, and Cincinnati) in terms of the four major components. No differences emerged. Finally, students' t-tests were used to make comparisons between respondents at the daytime workshops and respondents at the evening meetings; again, no differences were found. The lack of differences on mean scores among groups on the four components of meeting effectiveness suggests a consistent definition across diverse audience types. The similarity of evaluations across locations probably suggests the 


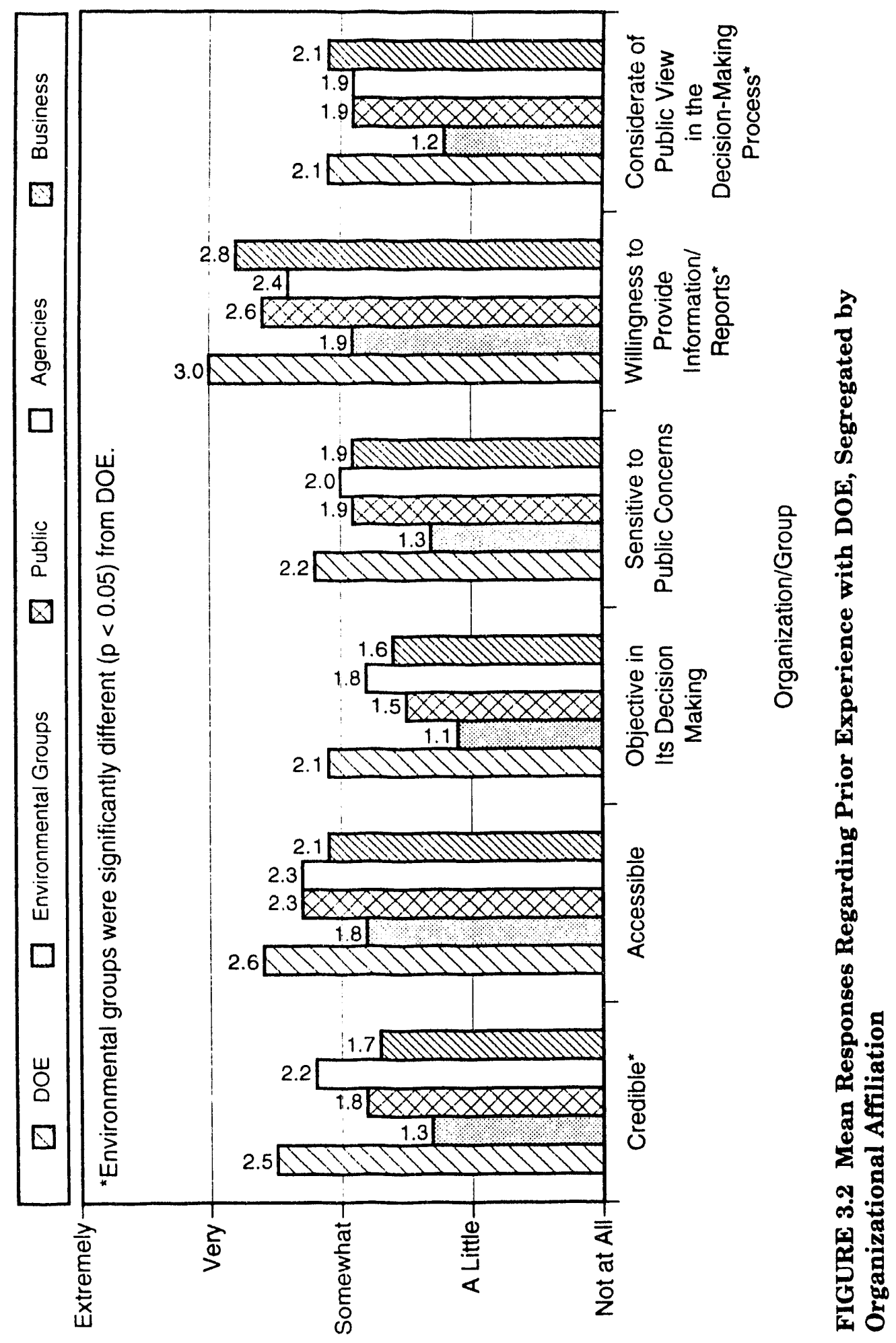


TABLE 3.6 Types of Resources Respondents Would Like for Providing Input to DOE

\begin{tabular}{|c|c|c|c|c|}
\hline \multirow[b]{2}{*}{ Type of Resource } & \multicolumn{2}{|c|}{ First Type } & \multicolumn{2}{|c|}{ Second Type } \\
\hline & Number & Percentage & Number & Percentage \\
\hline Nothing listed (missing) & 61 & 45.0 & 117 & 86.7 \\
\hline Information on specific issues & 19 & 14.1 & 5 & 3.7 \\
\hline Personal attention & 15 & 11.1 & 0 & 0 \\
\hline Choice of meeting times & 9 & 6.7 & 8 & 5.9 \\
\hline $\begin{array}{l}\text { Early notice of upcoming participation } \\
\text { opportunities }\end{array}$ & 6 & 4.4 & 1 & 0.7 \\
\hline Information in news media & 3 & 2.2 & 0 & 0 \\
\hline Conveniently located meetings & 3 & 2.2 & 0 & 0 \\
\hline Written information on DOE facilities & 1 & 0.7 & 0 & 0 \\
\hline Regular public meetings with DOE & 1 & 0.7 & 0 & 0 \\
\hline $\begin{array}{l}\text { Explanation of procedures for } \\
\text { participation }\end{array}$ & 1 & 0.7 & 0 & 0 \\
\hline Explanation of terms and abbreviations & 0 & 0 & 1 & 0.7 \\
\hline Access to decision making & 0 & 0 & 1 & 0.7 \\
\hline Other & 17 & 12.6 & 2 & 1.5 \\
\hline
\end{tabular}

TABLE 3.7 Questionnaire Items Covering Four Major Components of Meeting Effectiveness

Accessibility

- Availability of documents at the workshop

- Occurrence sufficiently early in the NEPA process

- Inclusion of all interested parties in the workshop

- Inclusion of the public in the decision-making process

- Early notice of upcoming DOE participation opportunities

- Public input to the agenda

Fairness

- Opportunity to evaluate the workshop

- DOE adherence to its procedures developed for participation

- Explanation of procedures for participation

Perceived understandability

- Ability to hold my interest

- Accuracy of the workshop presentations

- Understandability of the workshop

- Appropriate level of detail in the workshop presentations

- Explanation of specific issues

Empowerment

- DOE provision of opportunities for me to voice my opinion

- DOE willingness to listen to participants

- DOE openness to soliciting input from all parties

- DOE responsiveness to participants' concerns and suggestions 

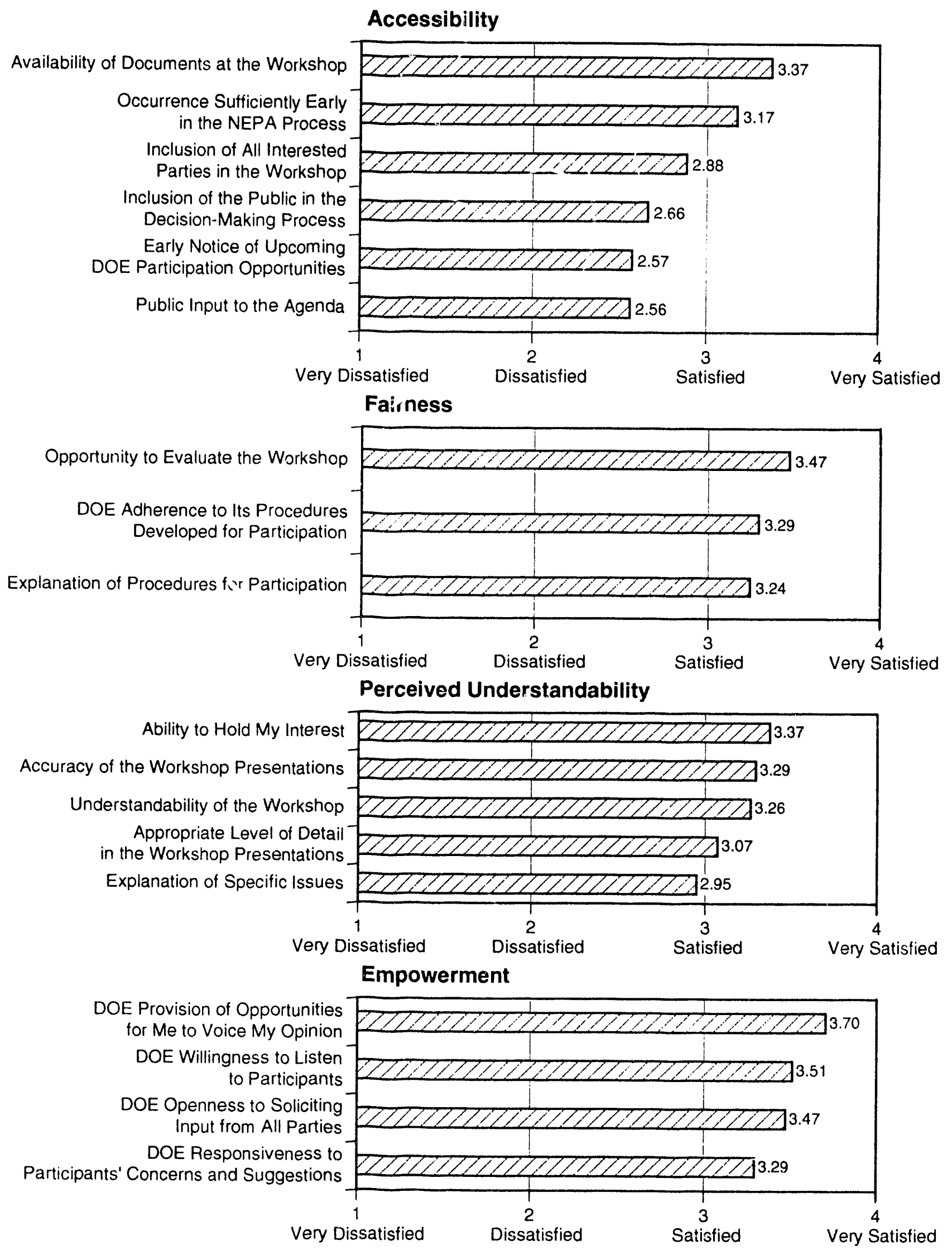

FIGURE 3.3 Mean Responses of Non-DOE Respondents on the Components of Meeting Effectiveness 
lack of regional differences in definitions of public meetings. Taken together, these results may suggest that DOE may use and/or develop more generic public participation activities. In other words, they do not need to be specifically tailored to geographic regions or special interest groups. This interpretation should be viewed cautiously, given the low attendance at all meetings and workshops. Those people not in attendance could have different views than respondents. The data collection effort and study design, however, do not allow investigation of such differences. The comparison of the daytime workshops and evening meetings shows that the participants viewed them similarly. Overall attendance was generally higher at the workshops than at the meetings, suggesting a preference for the workshop environment for those willing to attend.

\subsubsection{Accessibility}

Accessibility is defined as access to, or availability of, decision makers, information, and documents/reports. Several items were included on the workshop and meeting questionnaires to address accessibility:

- Availability of documents at the workshop or meeting,

- Occurrence of the workshop or meeting sufficiently early in the NEPA process,

- Inclusion of all interested parties in the workshop,

- Inclusion of the public in the decision-making process,

- Early notice of upcoming DOE participation opportunities, and

- Public input to the agenda.

In questionnaire responses, DOE was rated lower on accessibility than on fairness, perceived understandability, and empowerment (Figure 3.3). Respondents were satisfied that the meetings occurred early in the NEPA process and with the availability of documents at the workshop. ${ }^{6}$ Respondents were slightly more satisfied than less satisfied that the public was included in the decision-making process and that all interested parties were included in the workshops. They were essentially neutral about whether DOE gave early notice of upcoming DOE participation opportunities or whether the public could provide input into the agenda.

Focus group participants were somewhat more critical of DOE planning for the meetings than is reflected in questionnaire responses. They thought that DOE promoted the

6 Documents available at the workshop included copies of the implementation plan, a set of "information sheets," the report titled Environmental Restoration and Waste Management (EM) Program: An Introduction, a set of EM fact sheets, and the executive summary of the Environmental Restoration and Waste Management Five Year Plan: Fiscal Years 1993-1997. 
meetings inadequately. Participants also indicated that DOE field offices had inadequate information and insufficient lead time to use their local communication networks to inform the public in their locations. Respondents felt that poor coordination of promotional activities between DOE Headquarters and DOE field offices led to inadequate notification of interested groups and insufficient time for notification. Focus group participants also indicated that the mechanisms for public notification were not used effectively by DOE. Specifically, the newspapers selected for advertising the meetings did not cover a wide enough geographic area to notify all potentially interested parties, and the advertisements that were used did not provide enough information or catch people's attention. The participants felt that although the 800 number was a good idea, people were frequently unable to use it because the line was busy or the voice mailboxes were full.

Although questionnaire respondents rated availability of documents fairly high on the questionnaire, focus group participants indicated that some problems arose regarding accessibility of written materials. They indicated that designated public reading rooms at or near DOE facilities are excellent sources of information; however, these rooms frequently are not open at times convenient for the general public, and the participants were uncertain whether the documents could be checked out. A broader problem is that obtaining information from DOE requires knowledge of the correct person within the organizational structure. This requires that the public have knowledge of the system, which is generally not the case.

\subsubsection{Fairness}

Fairness refers to the rules that guide the conduct of public involvement and whether the rules were followed at the workshops/meetings. Three items were used to measure fairness:

- Opportunity to evaluate the workshop,

- DOE adherence to its procedures for participation, and

- Explanation of procedures for participation.

Questionnaire respondents rated "DOE's adherence to the procedures developed for participation" and "opportunity to evaluate the workshop" between satisfied and very satisfied ( $F^{\prime}$ gure 3.3). Focus group participants did not identify any issues regarding the rules for participation, although the use of impartial facilitators was viewed positively. 


\subsubsection{Perceived Understandability}

Perceived understandability refers to the respondents' ability to understand DOE presentations and written materials and to determine the accuracy of the material presented. Five items were used to measure perceived understandability:

- Ability to hold my interest,

- Accuracy of the workshop presentations,

- Understandability of the work hop presentations,

- Appropriate level of detail in the workshop presentations, and

- Explanation of specific issues.

Questionnaire respondents generally rated items regarding perceived uraderstandability between satisfied and very satisfied (Figure 3.3). They were most satisfied with the interest level they had with the meeting, followed by the accuracy of the presentation. Although less highly rated, they were still satisfied with the explanation of specific issues.

Focus group participants discussed issues related to understandability in some detail. Participants were particularly concerned with the readability of the written materials distributed before the meetings and those generally available in the public reading rooms. Most focus group members indicated that they were able to understand the material; however, they generally considered the reading level to be too high for the public, as most focus group participants felt the participating ptiblic lacks a sophisticated knowledge of DOE substantive issues. Basically, focus group pariicipants felt that more consideration should be given to identifying the potential audience for documents being produced; for example, technical staff members are interested in details, while the general public may find a summary document more useful. In terms of the oral presentations at the workshops, some focus group participants suggested these presentations were not technical enough for many of the participants.

\subsubsection{Empowerment}

Empowerment refers to participants' feeling that they have some impact on the decision-making process. It does not mean that DOE abdicates its decision-making authority but rather that DOE allows for the inclusion of others in the process of making decisions. Four items were used to measure empowernent:

- DOE provision of opportunities for me to voice my opinion,

- DOE willingness to listen to participants, 
- DOE openness to soliciting input from all parties, and

- DOE responsiveness to participants' concerns and suggestions.

Overall results on these questions were positive, with questionnaire respondents indicating satisfaction levels between satisfied and very satisfied (Figure 3.3). In fact, relative to the other three concepts, respondents gave the highest mean scores to empowerment. Respondents were particularly satisfied with DOE's provision of opportunities for the public to voice their opinions, with this mean score being higher than all other items concerning meeting effectiveness. They were still satisfied, although slightly less so, with DOE responsiveness to participants' concerns and suggestions.

Fucus group participants were concerned, however, about the extent of DOE's responsiveness to participants' concerns and suggestions. Extensive questioning arose about whether and how the public comments at the workshops and meetings would be used in the decision-making process. It was recognized that use of the comments cannot be reported on until the final IP and the draft EIS are published. A more basic issue was raised about whether these workshops were actually a part of the decision-making process or merely a public relations device.

Moreover, focus group participants indicated that DOE needs to be clear about the power that it is willing to give the public. Members of one focus group stated that the public is being given the idea that it will be allowed to make decisions, but that is not really the case. Furthermore, when DOE does not use all the public comments, it gives the impression that it does not keep its promises to the public. This, in turn, leaves participants with the impression that they are not being heard. It was suggested that DOE indicate clearly how the public's input will be used to avoid raising the public's expectations falsely. This requires more follow-up than DOE is currently providing on how input is or will be used.

\subsection{MEETING AND RESOURCE PREFERENCES}

In addition to information on the four components of effectiveness, respondents were asked on the questionnaires and in the focus groups about the resources that would enhance their ability to participate and about their preferences for meeting formats or characteristics.

Questionnaire respondents were given a list of characteristics and were asked to rate the desirability of the :haracteristics for DOE workshops. These characteristics included providing time to talk at workshops, having clearly stated objectives, having an agenda responsive to attendees' needs, and providing technically oriented workshops. The most important metting characteristics for respondents were to have meetings where diverse viewpoints are represented and to have an impartial facilitator (Figure 3.4). This was followed closely by the respondents' desire to have two-way communication. Discussion sessions and technically oriented sessions were important to respondents but received lower ratings than the other characteristics. 


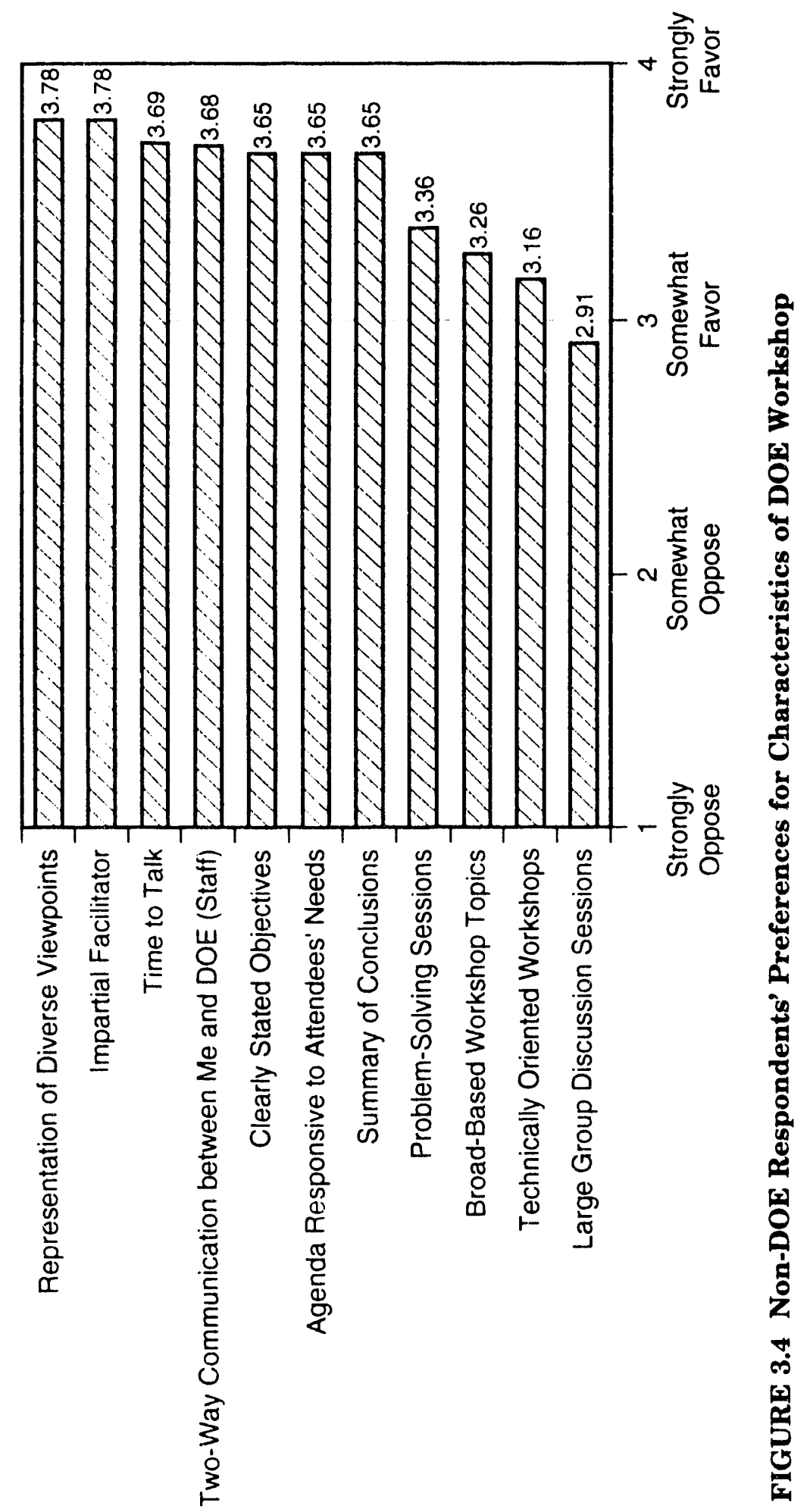


Focus group participants generally felt that the workshops were a step in the right direction for improving DOE's public participation efforts. They indicated that the format was well thought out, and the use of impartial facilitators was viewed positively. The small group format created an atmosphere that encouraged people to talk and facilitated dialogue rather than confrontation and grandstanding. However, participants felt that no one format works in all cases and that different approaches should be tried for different situations. Furthermore, focus group participants agreed the meetings were held at inconvenient locations and at inconvenient times. They also indicated that objectives were poorly specified and that participants needed to clearly understand the purposes and expectations of the public participation program if their involvement was to be effective.

Questionnaire respondents also were asked how they would like to learn about EM topics. All sources of information were seen as helpful for increasing respondents' understanding of environmental restoration and waste management topics, with the technical breakout sessions being most helpful and the premeeting material provided by DOE as being least helpful (although still viewed as "somewhat" helpful) (Figure 3.5).

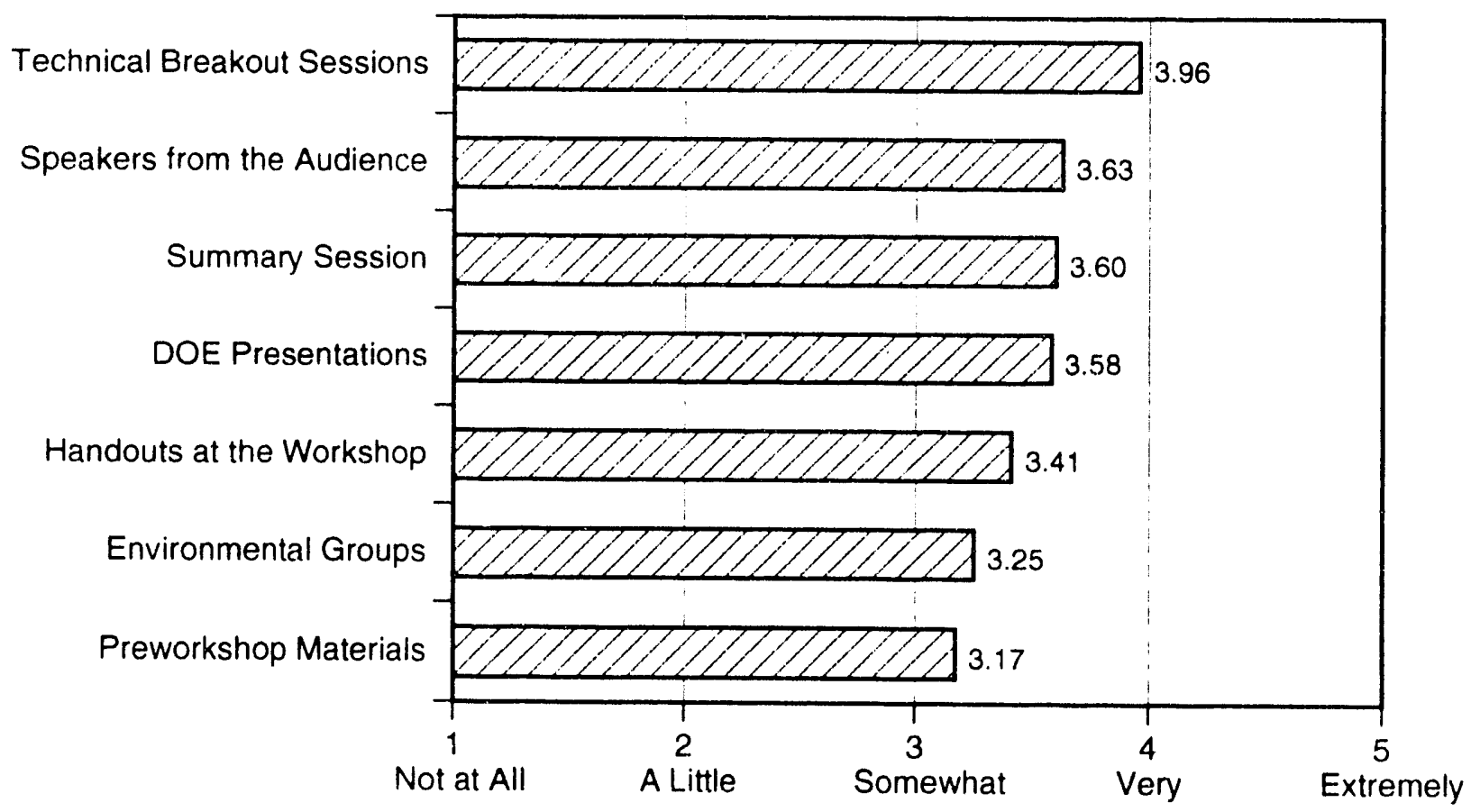

FIGURE 3.5 Non-DOE Respondents' Preferences for Information Sources to Increase Understanding of EM Topics 


\section{SUMMARY OF FINDINGS AND RECOMMENDATIONS}

The results presented in the following sections should be viewed with an awareness of several data limitations. Attendance was low at the meetings and workshops relative to initial expectations. Approximately $63 \%$ of all non-DOE attendees completed a questionnaire; those who participated in the focus groups volunteered for participation and hence were likely to be highly motivated. Focus group participants indicated that some important and relevant attendees were not present at the meetings; in fact, some groups were rumored to have boycotted these meetings. Hence, the data should be interpreted cautiously, as it may not be representative of potential attendees at DOE workshops and meetings.

This study also was not designed to address $s$ veral additional relevant questions. Because this evaluation focused on the meetings themselves, the following issues were not addressed:

- Evaluation of past DOE meetings,

- Changes in respondents' perspectives before and after the meetings and workshops,

- How respondents found out about the sessions,

- Respondents' ratings of the premeeting materials,

- Their perspectives on specific presentations held during the workshops,

- Whether the workshops and meetings actually contained the characteristics respondents desired, and

- Whether potential respondents actually attended the meetings and workshops.

Future evaluations may need to address these concerns.

Despite the data limitations, the results do provide guidance for future public participation efforts. Overall satisfaction was relatively high; questionnaire respondents indicated that they were between "satisfied" and "very satisfied." The results suggest that these workshops and meetings were considered fair, left participants feeling somewhat empowered, and provided adequate information. However, participants felt less satisfied with the accessibility to information and notification. Respondents indicated that they liked the specific characteristics of the workshop format. This public involvement effort differed considerably from typical meeting formats (Table 2.1), which seems to have been beneficial. Departures from typical meeting structure include the use of impartial facilitators and an opportunity for the public to evaluate the meetings. 
The results from the questionnaires suggest that DOE respondents and environmental group representatives significantly differed in their attitude toward DOE on the basis of prior experience. However, respondents were quite satisfied with these workshops and meetings, regardless of their organizational affiliations and despite prior negative experience by some. This suggests that the public participation process undertaken by EM to build credibility with these groups should continue and that prior negative experience need not be a stumbling block to better public involvement. While one might have expected regional differences, none emerged. The findings imply that respondents share a common definition of effective meetings and workshops and that a relatively generic structure seems to work for diverse groups, at least for national-level meetings that focus on programmatic issues. The written material and technical presentations, however, need to be carefully matched to audience needs and capabilities.

The major themes that emerged from the focus groups were generally consistent with the quantitative findings from the questionnaire, although somewhat less positive. Focus group participants generally were pleased with the extent of public involvement permitted by the workshop approach, although they felt a follow-up process was essential for real participation. Focus group participants were concerned about the poor attendance and felt that participants did not represent the concerned public. They also indicated that the public was not adequately involved in planning for the public meetings.

While the overall findings of this evaluation are positive, the participants indicated areas where DOE may improve its public participation efforts. Recommendations are organized around the four major components related to effectiveness: accessibility, fairness, perceived understandability, and empowerment. Functionally, the recommendations address useful changes in meeting structure, improvements in communication with the public, and improved coordination between DOE Headquarters and Departmental field offices.

\subsection{ACCESSIBILITY}

Questionnaire respondents gave relatively high ratings on satisfaction levels for many aspects of the workshops and public meetings; however, some of the lowest rankings (although not negative) indicated that DOE accessibility could be improved. Focus groups confirmed these findings.

The following recommendations apply to improving accessibility.

- Provide advance notice through adequate communications channels such as newspapers and letters to help increase the numbers of participants; most people need four to six weeks prior notice.

- Continue to provide documents to potential participants before the actual participation activities, as respondents were satisfied with the availability of documents. 
- Facilitate increased attendance through using existing communication networks within DOE (both Headquarters and Departmental field offices) and between DOE field offices and the public (including organized groups).

- Define the target audience for public involvement and plan meeting location and meeting content to meet the needs of the intended audience. This includes holding meetings closer to the sites, holding the meetings in public facilities rather than commercial buildings, holding meetings on Saturdays or in the evening when most people are not at work, and providing the appropriate level of material and presentations for the target audience.

- Incorporate field office perspectives and comments into future public involvement planning done by DOE Headquarters, including increasing the field offices' level of personal contact with DOE Headquarters. More specifically, solicit input from local organizations and from local field offices about whom to invite and what communication networks to access. Include labor unions and site employees. These groups were included in Cincinnati, where a local organization was involved in promoting and advertising the meeting.

- Improve the quality of advertising and promotional activities for public involvement and ensure that the geographic range of the distribution of information is appropriate to attract the target audience. Newspaper advertisements should be easily noticeable.

- Continue to send personal letters and follow-up letters to increase participation, consulting field office and local interest group mailing lists.

- Develop methods for integrating issues that cross DOE programmatic office boundaries so that the public is not confused about which organization is responsible for particular actions and who has access to information (e.g., waste management in EM versus reconfiguration of the weapons complex). Better integration also would reduce the cost of participation (in terms of time) for the public.

- Allow more opportunities for public input into meeting planning and agenda development.

- Consider flexible hours for DOE reading rooms and/or the use of organized groups as information centers (in addition to local libraries). 


\subsection{FAIRNESS}

Questionnaire respondents at the workshops and meetings indicated that they were satisfied with DOE's adherence to its own participation procedures and with the public's opportunity to evaluate the workshop. In terms of increasing the fairness of the meeting format, respondents were in favor of two-way communication, impartial facilitators, time to talk, clear objectives, and diverse viewpoints as elements in DOE workshops and meetings. Focus group respondents indicated the need for clear objectives for the workshops and the need for more flexible meeting formats. Most respondents were satisfied with the use of impartial facilitators to run the workshops and the meetings. Recommendations related to fairness follow:

- Hold meetings with more flexible formats that allow public input into the agenda and that provide more opportunity for the public to influence the structure of the meetings.

- Use small discussion groups with two-way communication, and provide time to talk so that diverse viewpoints are represented.

- Continue the use of impartial facilitators.

- Specify and clearly define objectives or purposes of workshops and meetings and adequately explain them to the public in advance of the meetings and workshops and at the beginning of each meeting and workshop.

- Allow attendees to evaluate public meetings and other public involvement activities, and use results to modify future public involvement activities.

\subsection{PERCEIVED UNDERSTANDABILITY}

Questionnaire respondents at the workshops and meetings were satisfied with the clarity of written material. They felt the presentations were accurate and held their interest. Respondents also found the preworkshop materials and the handouts at the workshops between "somewhat helpful" and "very helpful." Focus group participants indicated that the written material, although understandable to them, was written at a reading level higher than is appropriate for the general public. Participants also stated that the innovative use of graphics at the meeting contributed to the understanding of complex concepts and should be continued.

Questionnaire respondents indicated that understanding is increased through the use of technical breakout sessions, speakers from the audience, summary sessions, and DOE presentations. To a lesser degree, handouts, environmental groups, and premeeting materials also were helpful in increasing understanding. Some focus group participants felt that the workshops could have been more technical. 
Recommendations to improve participants' perceived understandability follow:

- Define target audiences and determine appropriate written materials for each audience type.

- Improve the readability of documents by lowering the reading level, or producing the same document at two different reading levels, and by providing summaries of long documents.

- Consider using groups concerned with DOE issues as repositories for information to facilitate public access to documents.

- Continue to provide accurate information. Presentations were likely enhanced by DOE's summary of its intended actions presented at the end of the workshops.

- Include graphics as part of information presentations.

- Ensure that detailed, substantive information is available for those who want specifics. The presence of technical staff was particularly helpful in this regard.

- Continue to provide presentations that foster interest in the topics and are appropriate for the target audience. This goal may be accomplished in many ways, including avoiding long, boring presentations and using dynamic speakers.

\subsection{EMPOWERMENT}

Questionnaire respondents generally felt empowered by the workshop/meeting process despite the reservation voiced in the focus groups about whether their comments would actually be considered in the decision-making process. A key to including the public in the decision-making process is to clearly define the role of the public. Identifying the process by which the public influences decisions is necessary to build a credible public involvement program. DOE demonstrated this during the meetings by summarizing how comments would be handled and by identifying action items related to comments. Implementing an effective mechanism for staying in touch with the public (feedback) would further enhance the feeling of empowerment. Recommendations regarding empowerment follow:

- Continue to demonstrate to the public how public comments will be used or explain why the comments were dismissed.

- Continue the approach of clearly tracking public comments and issue resolution. 
- Provide adequate feedback through follow-up meetings, personal interaction and communication, and regular correspondence.

- Continue with additional public involvement efforts that allow the public to be informed of the progress being made.

Although the ability to generalize from the evaluation results was limited by the relatively small turnout at the meetings and workshops, the questionnaire and the focus groups did indicate areas where DOE's efforts were successful as well as where changes could be made. The planning of future public involvement activities should take the suggested changes into consideration, not only to improve the efficacy of the activity itself but also to indicate concretely that DOE is responsive to public comments and suggestions. 


\section{REFERENCES}

CEQ (Council on Environmental Quality), 1986, "Regulations for Implementing the Procedural Provisions of the National Environmental Policy Act," Code of Federal Regulations, Title 40, Parts 1500-1508, § 1506.6.

Desvousges, W.H., and K.V. Smith, 1988, "Focus Groups and Risk Communication: The 'Science' of Listening to Data," Risk Analysis 8(4).

DOE (U.S. Department of Energy), 1991, Public Participation in Environmental Restoration Activities, DOE/EH-0221, Nov.

DOE, 1992, "National Environmental Policy Act Implementing Procedures; Final Rule (10 CFR Part 1021)," Federal Register 57:15122-15159, April 24.

Ertel, M.O., 1979, "A Survey Research Evaluation of Citizen Participation Strategies," Water Research 15(4), Aug.

Glass, J.J., 1979, "Citizen Participation in Planning: The Relationship between Objectives and Techniques," APA Journal, April.

Gundry, K.G., and T.A. Heberlein, 1984, "Do Public Meetings Represent the Public?" Research Report, Spring.

Hadden, S.G., 1981, "Technical Information for Citizen Participation," The Journal of Applied Behavioral Science 17(4).

Kasperson, R.E., 1986, "Six Propositions on Public Participation and Their Relevance for Risk Communication," Risk Analysis 6(3).

Rosener, J.B., 1978, "Citizen Participation: Can We Measure Its Effectiveness?" unpublished report, University of California, Irvine, Sept./Oct.

Syme, G.J., and E. Eaton, 1989, "Public Involvement as a Negotiation Process," Journal of Social Issues 45(1). 
APPENDIX A:

QUESTIONNAIRES FOR THE WORKSHOPS AND MEETINGS 


\section{Workshop Evaluation}

This questionnaire is part of an evaluation that is being conducterd by Argenne Natiomal Laboratory lo help the U.S. Department of Energy (DOE)/Envirommental Restoration and Waste Mlanagement plan heter ways to involve the puthic in its artivit However, your participation is important for use in improving $D() E$ 's public participation elforts.

Thank you for your assistance.

\begin{tabular}{|c|c|c|c|c|c|}
\hline \multicolumn{6}{|c|}{$\begin{array}{l}\text { Circle how satisfied you were with this workshop } \\
\text { in lerms of the following factors: }\end{array}$} \\
\hline \multirow[b]{2}{*}{$\begin{array}{l}\text { Explanation of procedures tor } \\
\text { participaltion }\end{array}$} & \multirow{2}{*}{$\begin{array}{c}\text { Versy } \\
\text { Disuritisified } \\
1\end{array}$} & \multirow{2}{*}{$\frac{\text { Cissattuled }}{2}$} & \multirow{2}{*}{$\frac{1 \text { stlisied }}{3}$} & \multirow{2}{*}{$\frac{\begin{array}{c}\text { very } \\
\text { sostisind d }\end{array}}{4}$} & \multirow{2}{*}{$\frac{\substack{\text { op } \\
\text { Opion }}}{x}$} \\
\hline & & & & & \\
\hline $\begin{array}{l}\text { DOE adherence to their } \\
\text { procedures develuped } \\
\text { for participation }\end{array}$ & 1 & 2 & 3 & 4 & $x$ \\
\hline $\begin{array}{l}\text { DOE responsiveness to } \\
\text { participants' concerns and } \\
\text { suggestions }\end{array}$ & 1 & 2 & 3 & 4 & $x$ \\
\hline 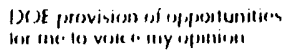 & 1 & 2 & 3 & 4 & $x$ \\
\hline 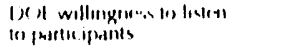 & 1 & 2 & 3 & 4 & $x$ \\
\hline $\begin{array}{l}\text { DUE opxinness io solic iling } \\
\text { inpul irom all parties }\end{array}$ & 1 & 2 & 3 & 4 & $\mathrm{x}$ \\
\hline $\begin{array}{l}\text { Occurrence sufficienlly early } \\
\text { in the Nationdl Environimental } \\
\text { Policy AcI (NEPA) proce'ss }\end{array}$ & 1 & 2 & 3 & 4 & $x$ \\
\hline $\begin{array}{l}\text { Early notice of upconning DOE } \\
\text { participation opportunities }\end{array}$ & 1 & 2 & 3 & 4 & $x$ \\
\hline Clarity of written material & 1 & 2 & 3 & 4 & $x$ \\
\hline Explanation of sperific issucs & 1 & 2 & 3 & 4 & $\mathrm{x}$ \\
\hline $\begin{array}{l}\text { Avalabulity oi documents } \\
\text { at the workshop }\end{array}$ & 1 & 2 & 3 & 4 & $x$ \\
\hline $\begin{array}{l}\text { Inclusion of the public in the } \\
\text { dectision-making prexess }\end{array}$ & 1 & 2 & 3 & 4 & $x$ \\
\hline $\begin{array}{l}\text { Inclusion of all interested } \\
\text { purties in the work tiop) }\end{array}$ & 1 & 2 & 3 & 4 & $x$ \\
\hline Public input to dgerndd & 1 & 2 & 3 & 4 & $x$ \\
\hline $\begin{array}{l}\text { Opportunity to evaluake the } \\
\text { workshop }\end{array}$ & 1 & 2 & 3 & 4 & $x$ \\
\hline $\begin{array}{l}\text { Accuracy of the workshop } \\
\text { presentations }\end{array}$ & 1 & 2 & 3 & 4 & $x$ \\
\hline $\begin{array}{l}\text { Understandability of the } \\
\text { workshop presentations }\end{array}$ & 1 & 2 & 3 & 4 & $x$ \\
\hline $\begin{array}{l}\text { Appropriate level of detail in } \\
\text { the workshop presentations }\end{array}$ & 1 & 2 & 3 & 4 & $x$ \\
\hline Ability to hold my interest & 1 & 2 & 3 & 4 & $x$ \\
\hline $\begin{array}{l}\text { Overall satisisction with DOE } \\
\text { at this workshop }\end{array}$ & 1 & 2 & 3 & 4 & $x$ \\
\hline Other (please specily) & & & & & \\
\hline$\ldots$ & 1 & 2 & 3 & 4 & $x$ \\
\hline$-+\ldots$ & 1 & 2 & 3 & 4 & $\mathrm{x}$ \\
\hline
\end{tabular}

\begin{tabular}{|c|c|c|c|c|c|c|}
\hline \multicolumn{7}{|c|}{$\begin{array}{l}\text { On the basis of your prior experience, } \\
\text { circle how you would rate DOE in terms of the following: }\end{array}$} \\
\hline & At NA & liute & Sorrinewhis & very & Etrenelv & (3) \\
\hline Cicdible & 1 & 2 & 3 & 4 & 5 & $x$ \\
\hline Accossible & 1 & 2 & 3 & 4 & 5 & $x$ \\
\hline $\begin{array}{l}\text { Objective in its } \\
\text { decision making }\end{array}$ & 1 & 2 & 3 & 4 & $j$ & $x$ \\
\hline Sensitive to public concerns & 1 & 2 & 3 & + & 5 & $\mathrm{x}$ \\
\hline $\begin{array}{l}\text { Willing lo provide } \\
\text { informaturivreports }\end{array}$ & 1 & 2 & 3 & 4 & 5 & $x$ \\
\hline 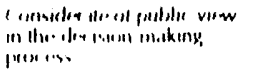 & 1 & 2 & 1 & 4 & 7 & $x$ \\
\hline
\end{tabular}

\begin{tabular}{|c|c|c|c|c|c|c|}
\hline $\begin{array}{l}\text { Circle how } \\
\text { in increasi } \\
\text { Environmental Restor }\end{array}$ & $\begin{array}{l}\text { you } \\
\mathrm{m} \text { a }\end{array}$ & $\begin{array}{l}\text { The i } \\
\text { und } \\
\text { id } W\end{array}$ & $\begin{array}{l}\text { ollowing } \\
\text { erstandif } \\
\text { ste Man }\end{array}$ & $\begin{array}{l}\text { wer } \\
\text { ge of } \\
\text { agger }\end{array}$ & ient top & \\
\hline & $\underset{N A N}{N o}$ & IAtile & Somrewthat & very & Fatrenely & Opinion \\
\hline Pre-workshop materials & 1 & 2 & 3 & 4 & 5 & $\mathrm{x}$ \\
\hline Handouts it the workshopp & 1 & 2 & 3 & 4 & 5 & $x$ \\
\hline Sperakers trom the audiencs: & 1 & 2 & 3 & 4 & 5 & $x$ \\
\hline DOE prexertations & 1 & 2 & 3 & 4 & 5 & $x$ \\
\hline Environmontal groups & 1 & 2 & 3 & 4 & $\mathbf{s}$ & $\mathrm{x}$ \\
\hline Texhnic al breakoul xissikms & 1 & 2 & 3 & 4 & 5 & $x$ \\
\hline Summary ension & 1 & 2 & 3 & 4 & 5 & $\mathrm{x}$ \\
\hline Other (please specily) & & & & & & \\
\hline 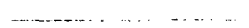 & 1 & 2 & 3 & 4 & 5 & $x$ \\
\hline - & 1 & 2 & 3 & 4 & 5 & $x$ \\
\hline
\end{tabular}

What did you do at the workshop (e.g., spoke publicly, appeared on TV, etc.)

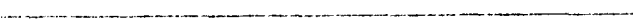

How would you like DOE to iell you dbout future workshops or meeting le.g., letter, newspaper, ferteral Register, etc.ls

Circle how strongly you feel that each of the following elements should be part of a DOE workshop:

\begin{tabular}{|c|c|c|c|c|c|}
\hline & rexplysy & $\begin{array}{l}\text { Soullewhot } \\
\text { Cppose }\end{array}$ & Somential & $\begin{array}{l}\text { Strongly } \\
\text { favive }\end{array}$ & $\begin{array}{c}\text { No } \\
\text { (spinumen }\end{array}$ \\
\hline 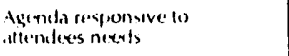 & 1 & 2 & 3 & 4 & $x$ \\
\hline Larger group dix usion wassions & 1 & 2 & 3 & 4 & $x$ \\
\hline $\begin{array}{l}\text { Two-way communic atwon } \\
\text { in.twern me and DOE Weatn }\end{array}$ & 1 & 2 & 3 & 4 & $x$ \\
\hline Impantial tacilitstur & 1 & 2 & 3 & 4 & $x$ \\
\hline Tume to talk & 1 & 2 & 3 & 4 & $x$ \\
\hline Clecurly stated objectives & 1 & 2 & 3 & 4 & $x$ \\
\hline Broad-based workshop lopics & 1 & 2 & 3 & 4 & $x$ \\
\hline Tex hnically oriented workstiops & 1 & 2 & 3 & 4 & $x$ \\
\hline Problern sulving arsions & 1 & 2 & 3 & 4 & $x$ \\
\hline $\begin{array}{l}\text { Representation or divere: } \\
\text { verwpoinls }\end{array}$ & 1 & 2 & 3 & 4 & $x$ \\
\hline surnnatry ot com lusem & 1 & 2 & 3 & 4 & $x$ \\
\hline \multicolumn{6}{|l|}{ Other iplesise yux lity) } \\
\hline$-\ldots \ldots$ & 1 & 2 & 1 & 4 & $x$ \\
\hline$\ldots \ldots+\ldots$ & 1 & 2 & 3 & 4 & $x$ \\
\hline
\end{tabular}

What would aid you in providing input to DOE on the NEPA process (e.g. persmal allention, (hoice of warkshep times, inlormation of speritic issuessl?

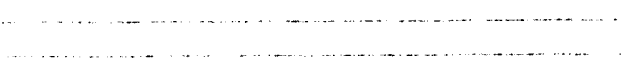

Why dirf vou conet to this work thopl

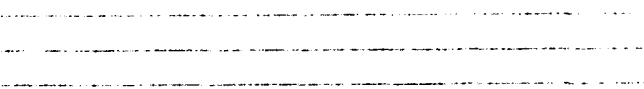

What dist you accomplish at this workshop le.g., voicerd iny opinion. lalked to environmental kroups, atc. ?

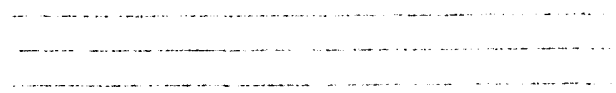

What organizaliesminstitution do you represent?

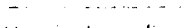

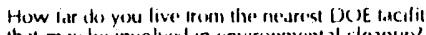
th.s masy be involued in envirommental deanup? What in your place on resulenke? Asilen, 


\section{Meeting Evaluation}

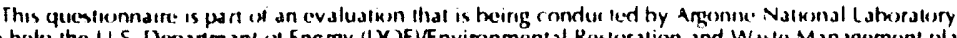
to help the U.S. Deparm ?nt of Energy (1) E)/Environmental Resteration and Waste Managernent plan

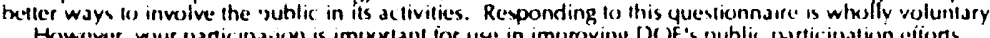



Thank you for your assistance.

\begin{tabular}{|c|c|c|c|c|c|}
\hline \multicolumn{6}{|c|}{$\begin{array}{c}C^{*} \text { cle how satisfied yous were with this public meeting } \\
\text { in terms of the following factors: }\end{array}$} \\
\hline & 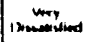 & I Dnentived & sonstied & (1) & (nement \\
\hline $\begin{array}{l}\text { Explarution of prex adures lor } \\
\text { purficipution }\end{array}$ & 1 & : & 3 & 4 & $x$ \\
\hline $\begin{array}{l}\text { DOE xitherens e to thest } \\
\text { proc elures developed } \\
\text { tor partic pation }\end{array}$ & 1 & 2 & 3 & 4 & $x$ \\
\hline $\begin{array}{l}\text { DOf rexponsiventss io } \\
\text { purticipants' concerns and } \\
\text { suggestions }\end{array}$ & 1 & 2 & 3 & 4 & $x$ \\
\hline $\begin{array}{l}\text { DOE proviston of oppertuniles } \\
\text { kr me to voke mr oqinion }\end{array}$ & 1 & 2 & 3 & 4 & $x$ \\
\hline $\begin{array}{l}\text { DOE willingness fo li way } \\
\text { lo particitinis }\end{array}$ & $:$ & 2 & 3 & 4 & $x$ \\
\hline $\begin{array}{l}\text { Dof phenmess to wolk iling } \\
\text { infut hiom all parties }\end{array}$ & 1 & 2 & 3 & 4 & $x$ \\
\hline $\begin{array}{l}\text { Occurence suficiently early } \\
\text { in the National Environmental } \\
\text { Policy Act INEPAI procens }\end{array}$ & 1 & 2 & 3 & 4 & $x$ \\
\hline $\begin{array}{l}\text { Early notke of uproming DOE } \\
\text { participution opportunities }\end{array}$ & 1 & 2 & 3 & 4 & $x$ \\
\hline Clarily of wotten matelal & 1 & 2 & 3 & 4 & $x$ \\
\hline Explarwition of spaxite istups & 1 & 2 & 3 & 4 & $x$ \\
\hline $\begin{array}{l}\text { Avaulability of dox umeerks } \\
\text { at the mefting }\end{array}$ & 1 & 2 & 3 & 4 & $x$ \\
\hline 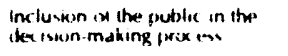 & 1 & 2 & 3 & 4 & $x$ \\
\hline $\begin{array}{l}\text { Incluwoun of all interessed } \\
\text { parties in the meting }\end{array}$ & 1 & 2 & 3 & 4 & $x$ \\
\hline Pullik ingual to dgencis & 1 & 2 & 3 & 4 & $x$ \\
\hline $\begin{array}{l}\text { Omomilinity to evaluale the } \\
\text { mieting }\end{array}$ & 1 & 2 & 1 & 4 & $x$ \\
\hline 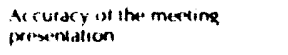 & 1 & 2 & 3 & 4 & $x$ \\
\hline $\begin{array}{l}\text { Undertandability of the } \\
\text { miet ing presenialion }\end{array}$ & 1 & 2 & 3 & 4 & $x$ \\
\hline  & 1 & 2 & 3 & 4 & $x$ \\
\hline Abulaty tis toold my intered & 1 & 2 & 3 & 4 & $x$ \\
\hline $\begin{array}{l}\text { Omeatl salisiaction with DOE } \\
\text { a this pultik metting }\end{array}$ & 1 & 2 & 3 & 4 & $x$ \\
\hline Othet flled dere ing & & & & & \\
\hline$\ldots \ldots$ & 1 & 2 & 1 & 4 & $x$ \\
\hline$\ldots$ & 1 & 2 & 3 & 4 & $x$ \\
\hline
\end{tabular}

\begin{tabular}{|c|c|c|c|c|c|}
\hline \multicolumn{6}{|c|}{$\begin{array}{l}\text { Circle he:v strongly you feel that each of the following } \\
\text { elements should be part of a DOE meeting: }\end{array}$} \\
\hline & werester & soriventide & sompontiol & 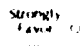 & $\left(\begin{array}{l}n \\
n+m, x\end{array}\right.$ \\
\hline 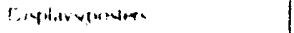 & 1 & 2 & 1 & + & $x$ \\
\hline Audiwatused promentations & 1 & 2 & 3 & 4 & $x$ \\
\hline Hanchuts: & 1 & $z$ & 3 & 4 & $x$ \\
\hline 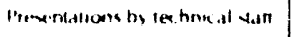 & 1 & 2 & 3 & 4 & $x$ \\
\hline L.arge grouft dive unwen wenton, & 1 & 2 & 3 & 4 & $x$ \\
\hline Peoldetm wolving emasn & 1 & 2 & 3 & 4 & $x$ \\
\hline 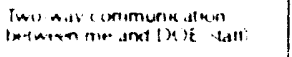 & 1 & 2 & 1 & 4 & $x$ \\
\hline 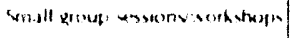 & 1 & 2 & 3 & 4 & $x$ \\
\hline Lerture lexmost & 1 & 2 & 3 & 4 & $x$ \\
\hline 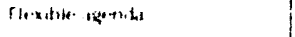 & 1 & 2 & 3 & 4 & $x$ \\
\hline  & 1 & 2 & 3 & 4 & $x$ \\
\hline & 1 & : & 3 & 4 & $x$ \\
\hline & : & ? & $i$ & 4 & $x$ \\
\hline
\end{tabular}

\begin{tabular}{|c|c|c|c|c|c|c|}
\hline \multicolumn{7}{|c|}{$\begin{array}{l}\text { On the basis of your prior experience. } \\
\text { circle how you would rate DOE in lerms of the following: }\end{array}$} \\
\hline \multirow[b]{2}{*}{ Crestilste } & $N_{N=1}^{N x}$ & inte & Sementher & wer & foterneny & intinem \\
\hline & 1 & 2 & 3 & 4 & j & $x$ \\
\hline Accessible & 1 & $:$ & 3 & 4 & 3 & $x$ \\
\hline $\begin{array}{l}\text { Ohjective in its } \\
\text { checiston making }\end{array}$ & 1 & 2 & 1 & 4 & i & $x$ \\
\hline \multirow{2}{*}{$\begin{array}{l}\text { Senstive to public concerns } \\
\text { Willing to provide } \\
\text { inlormationvreyorts }\end{array}$} & 1 & 2 & 3 & 4 & j & $x$ \\
\hline & 1 & 2 & 3 & 4 & 5 & $x$ \\
\hline $\begin{array}{l}\text { Consuderste of public viow } \\
\text { in the decison.making } \\
\text { process }\end{array}$ & 1 & 2 & 3 & 4 & 3 & $x$ \\
\hline \multicolumn{7}{|c|}{$\begin{array}{l}\text { Circle how halpful the following ivere } \\
\text { in increasing your understanding of } \\
\text { Environmentici Restoration and Waste Management topics: }\end{array}$} \\
\hline \multirow{5}{*}{$\begin{array}{l}\text { Prerneeting materials } \\
\text { Handouts at the meteting } \\
\text { Spedkers from the audience } \\
\text { DOE prevntations }\end{array}$} & 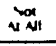 & inke & wherwhel & ver & Estrementy & cancoun \\
\hline & $:$ & 2 & 3 & 4 & 5 & $x$ \\
\hline & 1 & 2 & 3 & 4 & 5 & $x$ \\
\hline & 1 & 2 & 3 & 4 & $j$ & $x$ \\
\hline & 1 & 2 & 3 & 4 & 5 & $x$ \\
\hline \multirow{3}{*}{$\begin{array}{l}\text { Environmental groupis } \\
\text { Technikal breathoul sessions } \\
\text { Summary session } \\
\text { Other (please ymacity) }\end{array}$} & 1 & 2 & 3 & 4 & 3 & $x$ \\
\hline & 1 & $\therefore$ & 3 & 4 & 5 & $x$ \\
\hline & 1 & 2 & 3 & 4 & 5 & $x$ \\
\hline \multirow{2}{*}{${ }_{-1}+\ldots$} & 1 & 2 & 3 & + & 5 & $x$ \\
\hline & 1 & 2 & 3 & 4 & 5 & $x$ \\
\hline
\end{tabular}






APPENDIX B:

SUMMARY OF DOE QUESTIONNAIRE RESPONSES AND FOCUS GROUP FINDINGS 


\section{APPENDIX B:}

\section{SUMMARY OF DOE QUESTIONNAIRE RESPONSES AND FOCUS GROUP FINDINGS}

\section{B.1 DATA COLLECTION}

Data were collected from U.S. Department of Energy (DOE) personnel using both questionnaires and focus groups. The same approach was followed for DOE personnel as was used for all other participants (Section 2).

\section{B.2 RESULTS OF QUESTIONNAIRES FROM DOE STAFF AND CONTRACTORS}

According to the questionnaire, DOE staff and contractor respondents were overall most satisfied in the areas of fairness, understandability, and empowerment (Figure B.1). They were relatively less satisfied with accessibility. However, the highest individual level of satisfaction was with the accessibility measure of "availability of documents at the workshop." They also were relatively satisfied that these meetings and workshops occurred sufficiently early in the National Environmental Policy Act (NEPA) process. The responses on these indicators were essentially the same (i.e., not statistically different) as for all other people attending the meetings.

In terms of fairness, DOE indicated high satisfaction with both "the opportunity to evaluate the workshop" and with "adherence to the procedures developed for the workshop." In the area of perceived understandability, DOE was most satisfied with "the appropriate level of detail at the workshops." Finally, in terms of empowerment, the highest level of satisfaction was with "DOE's willingness to listen to participants." DOE expressed the least satisfaction (between dissatisfied and satisfied) with "early notice of upcoming DOE participation opportunities" and "inclusion of all interested parties in the workshop."

\section{B.3 DOE STAFF AND CONTRACTOR FOCUS GROUPS}

Participants in the DOE focus groups felt that the overall experience was a positive one for DOE in terms of beginning to connect with the public. They also stated that the small group environment was more comfortable for them (as well as being more comfortable for the public). DOE's relative dissatisfaction with the inclusion of all interested parties is supported by the focus group comments on Headquarters' inadequate use of field office mailing lists and communication networks. Field office representatives felt that they were in a better position to identify who should be invited and then to extend invitations to them. DOE focus group findings were similar to the public focus group findings, indicating a shared definition of what constitutes good public meetings. 


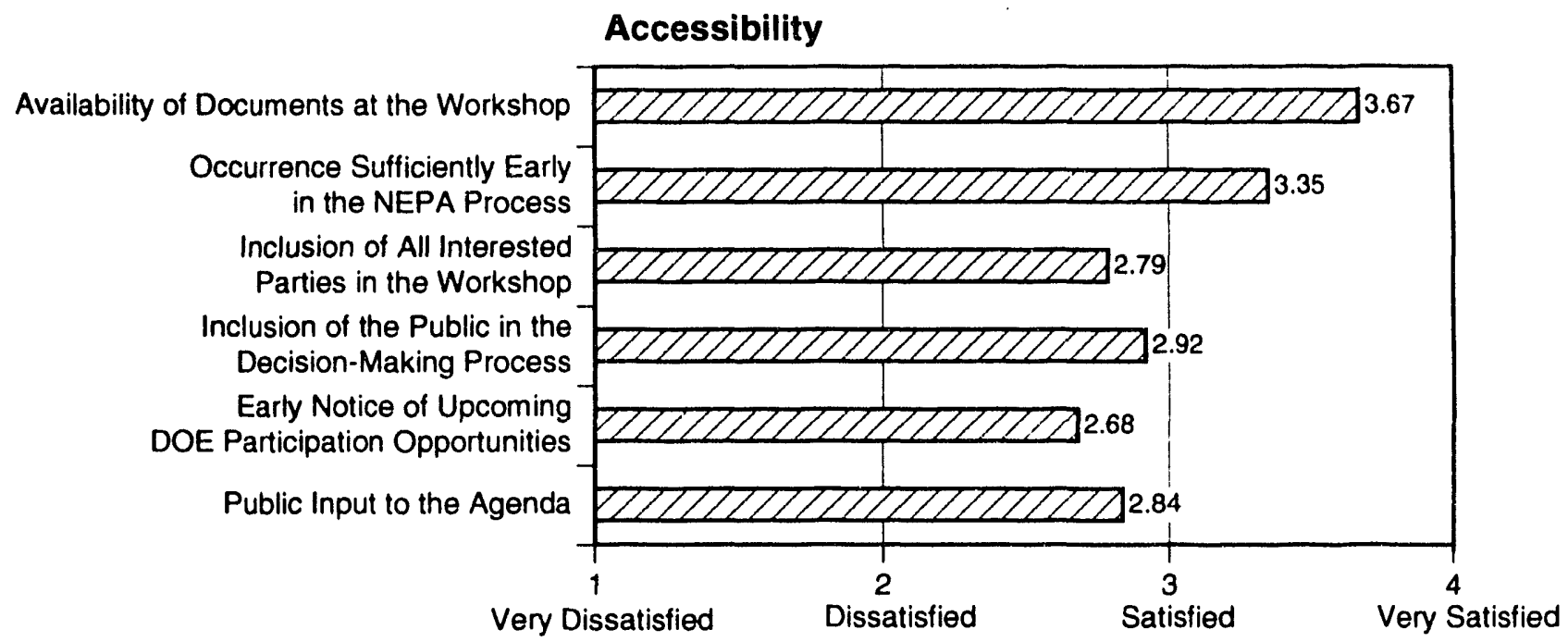

Fairness

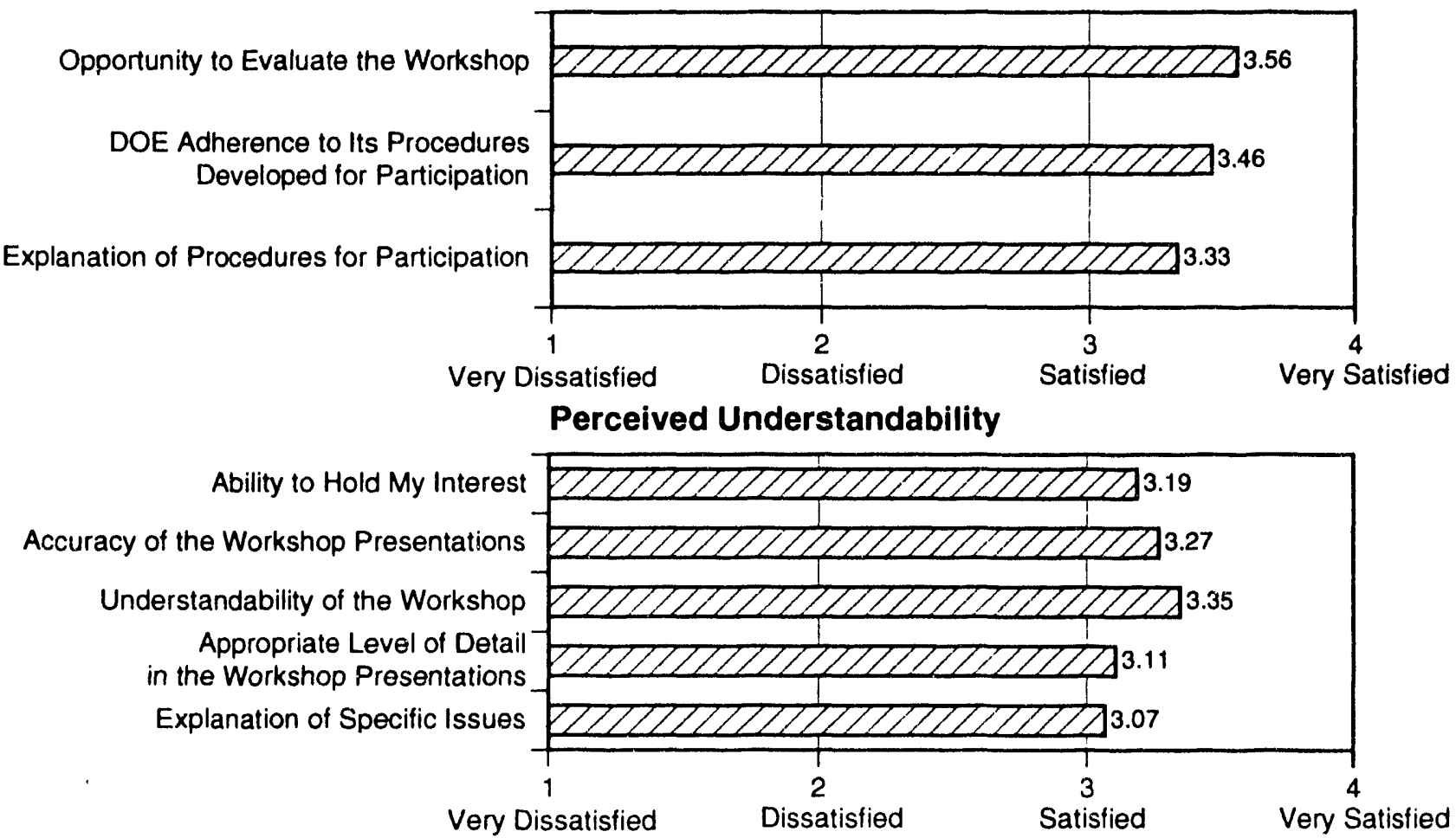

\section{Empowerment}

DOE Provision of Opportunities for Me to Voice My Opinion

DOE Willingness to Listen to Participants

DOE Openness to Soliciting Input from All Parties

DOE Responsiveness to

Participants' Concerns and Suggestions

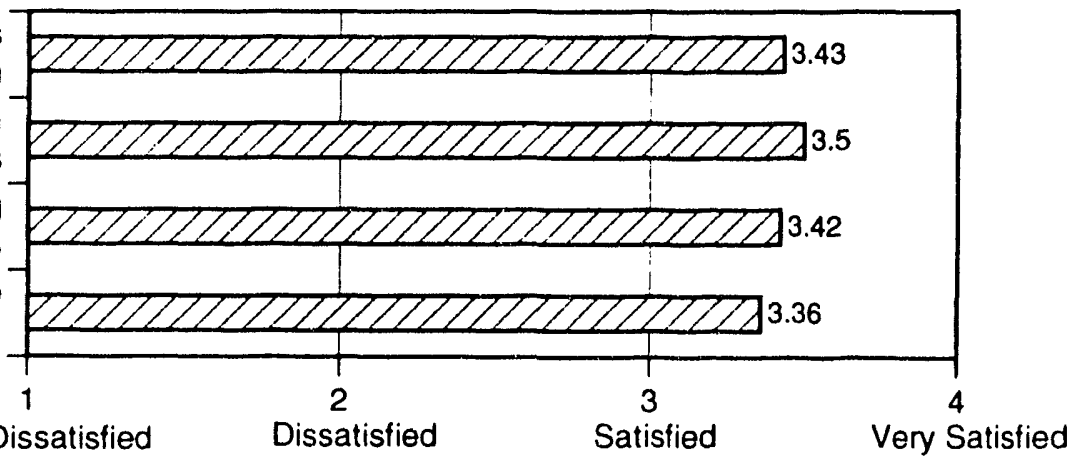

FIGURE B.1 Mean Responses of DOE Staff and Contractors on the Components of Meeting Effectiveness 


\section{B.4 DOE FOCUS GROUP FINDINGS}

This section provides more detail on findings identified by DOE focus group participants and associated recommendations from the focus groups in each city. Table B.1 summarizes these findings for the major components of meeting effectiveness (accessibility, fairness, perceived understandability, and empowerment).

\section{B.4.1 Atlanta}

1. Finding (accessibility): Attendance was low, and representation was limited.

The concern about the low attendance and the unrepresentative nature of those who did attend reduced the overall value of the meetings as a vehicle for public involvement. The low attendance was most likely attributable to the fact that DOE did not target specific audiences and invite them and that the locations of the meetings were not really convenient to those who would be most interested in attending (the people living around the sites).

Recommendation: DOE must first identify the audience that it wants to attract and then use the tools appropriate for that audience. If interaction with opinion leaders is an objective, DOE must go to those leaders. In general, meetings should be closer to where the prospective audience lives. DOE also should broaden the base of the potential audience beyond the traditional environmental groups to include organizations such as local business leaders, city council members, and the National Association for the Advancement of Colored People (NAACP). These people also have a stake in DOE's actions.

2. Finding (empowerment): DOE will not keep the promises that it makes to the public.

Meetings of this type give the impression that all public comments will be used. This, however, may not be the case. DOE should clearly indicate how it will use the input from the workshops to avoid raising the public's expectations falsely. DOE must not state or imply that it will take certain actions if it cannot actually do so. If DOE makes commitments and then does not follow through, the credibility problem will be further exacerbated.

Recommendation: No recommendation is suggested for this finding. 


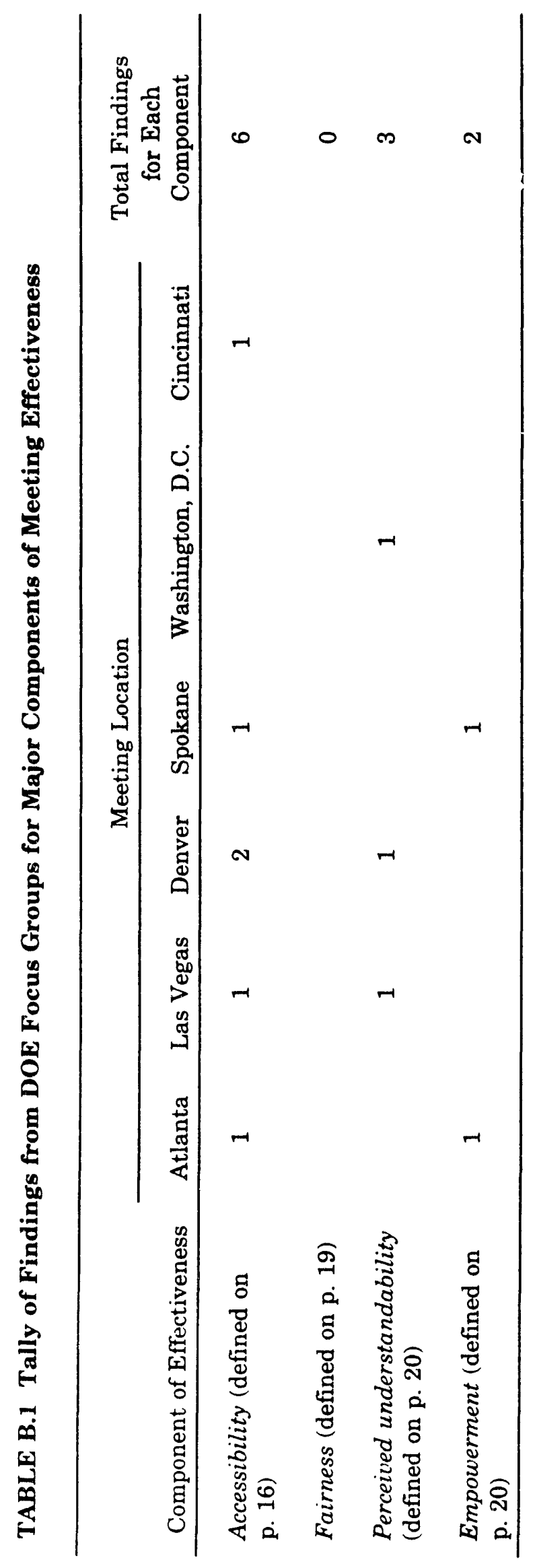




\section{B.4.2 Las Vegas}

1. Finding (accessibility): Attendance was low, and representation was limited.

This finding is attributable to several factors. First, poor coordination between the field office and Headquarters resulted in inadequate promotion of the meeting and in the limited range of those invited. Second, no linkage was established between local/site issues and the national theme. The public did not connect the national environmental impact statement (EIS) with local concerns and consequently was not very interested. Third, the location of the meeting was not designed to attract the general public.

Recommendation: The field offices should be closely involved in the process of identifying potential invitees and in inviting them. The range of groups to be invited should be broader than environmental groups, and key decision makers and opinion leaders should be personally invited. The range of participants could be broadened through increased DOE involvement in the education system.

The strategy for presenting a national document (i.e., the programmatic EIS) should be to link it to local concerns and issues. This would indicate to the public that it needs to be directly involved.

The location of a meeting is very important in terms of promoting attendance. The meetings should be taken to the people. In this case, they should be near the sites. Furthermore, the meetings should be held in public buildings, not in hotels.

2. Finding (perceived understandability): Written materials are not easily understandable.

The level of writing must be appropriate for the audience being addressed. DOE must identify the levels that are represented and gear the written material to those levels.

Recommendation: Hire a consultant to translate the complex technical material into more understandable language.

\section{B.4.3 Denver}

1. Finding (accessibility): Attendance was low, and representation was limited. 
The low attendance was attributable to several factors. The primary one was the lack of adequate field office involvement in planning the structure of the meetings and in determining who should be invited, including which local DOE personnel should participate. A second factor was the meeting locations. A third factor was the time of day when the meetings were held.

Recommendation: Headquarters should allow field offices greater involvement in planning the structure of the meeting and in determining who should be invited. The field office has better knowledge of the people in the area and would know how to encourage more people to attend. The field office could provide the higher level of personal contact that is needed.

Meetings should be held near the sites. In this case, more meetings would have been required, but a larger number of people would have been involved. Having more meetings might also reduce the number of DOE staff at any one meeting because only staff from the particular site, rather than staff from all sites in the region, would need to be present.

The meetings must be held in the evenings if DOE wants the general public to attend.

2. Finding (perceived understandability): Written materials are not easily understandable.

The problem remains of the general public understanding the IP; something more needs to be done. Part of this problem relates to DOE's poor identification of its audience. Identifying specific audiences would facilitate developing appropriate materials.

Recommendation: It might be useful to have two (or more) documents written at different levels, or a separate summary could be written for the IP. The summary can be less technical and written for the average person. The Public Affairs staff should be involved in writing the sumruary to ensure readability.

3. Finding (accessibility): The meeting formats should be more flexible.

The format of the meeting has a large influence on how effectively the message is conveyed to the public. The public should be allowed to identify preferred formats, and the meeting format should be consistent with the objective of the meeting.

Recommendation: The format of the meeting should be determined by the meeting objective and the types of issues to be discussed. The 
format also should be responsive to the amount of time the public wants to commit to the exercise. It is desirable to have both informal meetings for sharing information and formal meetings for feedback.

The small discussion group is a useful format, but every group does not have to discuss every topic. People should participate in several groups so that the dynamics will vary. A better way to organize the sessions might be to give the entire group a sampling of topics, then define the breakout sessions according to topics of interest.

\section{B.4.4 Spokane}

1. Finding (accessibility): Attendance was low, and representation was limited.

This concern partially stems from a poor definition of the public of interest. To employ the most appropriate formats and to create materials at the correct level of technical detail, the public that is being addressed must be clearly defined. Consideration must be given to both the "general public" and interested specialized groups (such as labor unions).

Recommendation: DOE must identify what the public wants and values before it can establish effective public involvement. This requires not only identifying various groups but interacting with them. Better use of local environmental groups in the networking process might have increased attendance. Linking the PEIS to site and local issues would have helped raise the interest level of the public. This type of linkage could have been accomplished in the newspaper advertisements and might have attracted more attention.

2. Finding (empowerment): DOE should be clear about the power that it is willing to give the public.

In terms of empowerment, DOE needs to be honest with the public. The public is being given the idea that it will be allowed to make decisions, but that is not really the case. This misapprehension will create antagonism and mistrust later. In the eyes of the public, participation is still a hollow term because no substantive actions have followed up rhetoric in the past.

Recommendation: DOE must think about how empowerment will actually happen. The public needs to understand the range of decisions that still can be made. Some commitments already are in place; the 
public should be told what these commitments are, so that they can make informed demands.

\section{B.4.5 Washington, D.C.}

1. Finding (perceived understandability): DOE should not underestimate public interest.

The public is interested in waste management and other site-related issues but often may not understand them. Issues need to be explained in language that can be generally understood. Increasing public interaction with the sites also can contribute to increasing understanding about site activities and problems.

Recommendation: One site indicated that annual open houses at the facility had proven to be a successful way of increasing public understanding and knowledge. This idea might be extended to other sites.

\section{B.4.6 Cincinnati}

1. Finding (accessibility): Attendance was low, and representation was limited.

Poor meeting notification was a major contributor to this problem. The appropriate people were not notified in a timely manner, and the objectives of the workshop were not clearly described to the public. If people are to be motivated to participate, they must understand what the participation entails and what they will gain from it.

Recommendation: To improve the distribution of information about the meeting, field offices need to be involved in identifying the invitees and in notifying them.

The advertisements for the meeting must state its purpose more clearly; for example, is the intent to get the general public involved directly or to access more knowledgeable groups who would then inform the public? Greater clarity and detail in the advertisement would have given the public a better idea of what to expect. This might have led to greater attendance. This lack of clarity also extended to the format of the workshop; the public had difficulty understanding the overall structure, which hampered participation. 
APPENDIX C:

SUMMARY OF PUBLIC FOCUS GROUP FINDINGS 


\section{APPENDIX C: \\ SUMMARY OF PUBLIC FOCUS GROUP FINDINGS}

This appendix summarizes the findings and associated recommendations expressed at the public focus group sessions in each city. Table C.1 presents the findings categorized by the major components of meeting effectiveness (accessibility, fairness, perceived understandability, and empowerment).

\section{C.1 ATLANTA}

1. Finding (accessibility): "Compartmentalization" of the waste issue makes participation more difficult.

The federal government divides the topic of waste management among several agencies, the most prominent being the U.S. Department of Energy (DOE) and the U.S. Department of Defense (DOD). Within DOE, waste management is divided among many program offices. This arrangement is difficult for the public to understand or to easily get information on the complete issue. It also requires the public to attend more public meetings than may be possible given limited resources.

Recommendation: For this issue to be addressed in a holistic way, programs need to be better integrated, at least in terms of how the information is presented to the public. The distinctions that DOE makes between program offices are relatively meaningless to the public and should not be the basis for organizing public involvement activities.

2. Finding (accessibility): Attendance was low, and representation was limited.

Participants felt that the low attendance was a result of the choice of meeting location and the general public's lack of knowledge about the subject.

Recommendation: If DOE wants the public to attend, the meetings must be held in convenient locations. To increase the public's knowledge of the subject, DOE has to start educating the public early and should become involved in the education system in a balanced way. This could be accomplished by participating in panel discussions with other types of organizations.

3. Finding (empowerment): Public comments will not be used by decision makers. 





These meetings and workshops represented a great improvement in DOE's public relations efforts. However, the public is still skeptical about the importance of its input into the decision-making process. The consensus was that the content of the final implementation plan and the draft environmental impact statement (EIS) would indicate how seriously public comments were considered.

Recommendation: No recommendation is suggested for this finding.

\section{C.2 LAS VEGAS}

1. Finding (accessibility): Information is not easily accessible.

It is necessary to know the structure of DOE to get the correct person to answer questions. The compartmentalization within DOE limits the exckange of information within the agency and in turn makes it more difficult for the public to obtain information.

Recommendation: DOE needs more than a public relations person; it needs to hire people who know the range of available information. These people would be knowledgeable about several programs or areas.

2. Finding (accessibility): DOE has not clearly defined its audience.

The public focus group questioned what audience the workshops were designed to attract and whether that audience was attracted. Another related questio. 1 is whether the audience that DOE hopes to attract is broad enough to provide representative input.

Recommendation: No recommendation is suggested for this finding.

3. Finding (accessibility): Attendance was low, and representation was limited.

This problem was attributable to inadequate promotion by DOE and to the fact that most people are not technically conversant with the issues. Without adequate knowledge, they do not feel competent to participate in this type of forum.

Recommendation: DOE should make use of local knowledge in identifying participants. Local groups should be used in promoting the meeting.

To increase the technical knowledge of the public, DOE should become involved in the education system. DOE's involvement in the schools 
would be acceptable if it were part of a balanced presentation of the issues.

4. Finding (empowerment): Meetings may not represent real public involvement in the decision-making process but only serve a public relations function.

The question concerns the difference between providing input and being involved in decision making. It is not clear to the public whether or how the input will be used by DOE. Focus group participants felt that DOE already had made a decision and that consequently the public's input will have no effect.

Recommendation: DOE should seriously examine public suggestions, provide feedback on the analysis and whether the suggestion was used, and offer an explanation if it is not used.

\section{C.3 DENVER}

1. Finding (accessibility): Attendance was low, and representation was limited.

Several factors contributed to this problem. First, DOE did not tap into the right local networks; consequently, the message did not get to the audience that DOE was trying to attract. Second, DOE was not really clear about its desired audience. Because the various interested groups were not identified, DOE did not tailor the message or the participatory technique that it used. A third contributing factor to the low attendance was that the public responds better to personal invitations than to blanket notifications. Finally, participants indicated that inconvenient and unfamiliar locations are likely to discourage attendance.

Recommendation: DOE should have solicited input from local organizations and from the local field office about whom to invite. In most cases, local organizations would have been happy to tap their own networks. The message and the format of public meetings should be tailored to a particular type of audience. Meetings designed for audiences of different levels of sophistication and knowledge would have been more effective. Local leaders should have been invited personally by DOE, and the mass mailing should have been followed up. Finally, the meetings should have been closer to the sites and staged in ordinary public buildings. This type of location would have been more convenient and more comfortable for the general public.

2. Finding (accessibility): The objectives of the workshops were not clear. 
The public should have a clear idea of what is going to happen at the workshops and what participation will involve. In this case, the attendees were unsure about their role and what they needed to know to participate effectively. This was partially because not all participants had an opportunity to review the IP in advance.

Recommendation: No recommendation is suggested for this finding.

3. Finding (accessibility): Public input was not solicited for meeting planning and agenda setting.

Public involvement should start at the beginning of the process (the planning phase). The opportunity to determine the format and subject matter would have increased the public's interest in attending.

Recommendation: The public should determine how it would like to participate as well as what topics it would like to discuss. If this is not possible before the meeting, then input of this sort (subject matter) should be allowed at the meeting.

4. Finding (empowerment): Public comments will not be used by decision makers.

The question is one of knowing whether comments will make a difference and whether DOE was really listening. This cannot be determined until the final IP or the draft PEIS is issued.

Recommendation: Identifying actions to be taken in response to comments might give the public more confidence that its comments are having some effect.

\section{C.4 SPOKANE}

1. Finding (accessibility): The meeting planning and agenda setting lacked public input.

Effective public involvement requires soliciting input from interested groups early in the process. The public needs to be involved in planning the meeting, identifying the objectives and potential outcomes, and selecting locations.

Recommendation: No recommendation is suggested for this finding.

2. Finding (accessibility): Written materials are not easily accessible. 
The accessibility of written information is a problem. The public reading rooms are not open at times that are convenient to the general public, and it is not clear whether the documents may be checked out. In addition, obtaining information requires identifying the correct person in the system; this requires that the public have knowledge of the system.

Recommendation: A listing (catalog) of available documents with a brief description of each would be helpful, particularly for people in outlying areas. Without knowledge of the DOE system and structure, it is difficult for the public to obtain information. Mechanisms for helping the public better understand the system could include news articles on the environmental impact process to provide a better basis for meetings and workshops and publishing a directory of DOE contacts in the local press.

3. Finding: DOE's credibility could be improved through the use of other information sources.

DOE's credibility could be improved through increased public education by non-DOE entities in areas such as human health, risk assessment, health risk, and radiation. This could increase the agency's credibility by confirming the results and analyses of reports and studies that DOE already has done.

4. Finding (perceived understandability): Written materials are not easily understandable.

The information provided to the public must be simplified. Documents should be short and written in everyday English at a tenth-grade reading level. If longer documents are necessary, summaries should be provided. In creating a document, both its purpose and the intended audience must be clearly defined.

Recommendation: To respond to a range of audiences, several tiers of documents should be developed, starting with a very simple one. Developing appendixes may be a way of providing more detail for those who want it (for example, regulators).

\section{C.5 WASHINGTON, D.C.}

1. Finding (accessibility): The objectives of the workshop were not clear. Participation is facilitated when participants understand the objectives of the meeting and their role in it. 
Recommendation: The objectives and the subject matter of each breakout session should be defined clearly. The participants should know what is going to happen in each session and what is expected of them. Whether the discussion was on the IP specifically or on the PEIS in general should have been clarified.

2. Finding (accessibility): Written materials are not easily accessible.

The lack of material provided in advance made participation more difficult. Participants are less likely to ask questions if they feel they are not prepared. Also, it was not clear whether participants were allowed to comment if they had not read the material.

Recommendation: No recommendation is suggested for this finding.

3. Finding (accessibility): Attendance was low, and representation was limited.

This was attributable primarily to the location of the meetings. The inconvenient locations were likely to discourage grassroots groups, which resulted in the limited representation and the limited dialogue that took place.

Recommendation: If $\mathrm{DOE}$ wants broad public representation, the meetings have to be located in convenient places.

4. Finding (accessibility): "Compartmentalization" of the waste issue makes participation more difficult.

The structure of the breakout groups reflected the compartmentalized approach that DOE takes to the topic of waste. The organization of the groups resulted in some topics of interest not being addressed; also, it was difficult to raise issues that were not discussed in the IP.

Recommendation: The breakout groups should be organized by topic rather than by DOE organizational structure. Related topics should be grouped in a session, and the appropriate resource people should be invited.

\section{C.6 CINCINNATI}

1. Finding (accessibility): Attendance was low, and representation was limited.

Several factors contributed to the attendance concern. First, to be effective, promotional information must reach people in sufficient time 
for them to respond. The mechanisms used should provide adequate opportunity for the public to obtain necessary information. Second, if working people are the target audience, the meeting time and location must be considered in light of constraints on working people. Finally, the range of groups contacted was not broad enough to cover all the interests that might be impacted. This brings into question the representativeness of the input obtained.

Recommendation: Advance notice is very important for increasing the response rate. Four to six weeks notice is considered adequate.

The mechanisms for public notification were not very effective. Newspaper advertisements should be carefully reviewed to ensure that they contain all the necessary information. An 800 number is a good idea, but DOE should ensure that callers are able to get through to DOE or leave a message.

The location and time of the meeting were not convenient for the working public. The meetings should be held nearer to the sites, in public buildings, and on Saturdays.

Local groups should be contacted to assist in developing the mailing list.

2. Finding (accessibility): The workshop follow-up process is lacking.

Once the participation process has started, it is important that DOE participants continue to be accessible to the interested public and that information about the process continues to be transmitted. This type of follow-up is important in building credibility for both DOE and the citizen involvement process.

Recommendation: Addresses and phone numbers of DOE staff should be available so that the public can follow up on issues.

Documentation of DOE's responses to the public comments and discussion should be distributed to those who attended the workshop. 
APPENDIX D:

SURVEYING POTENTIAL ATTENDEES 


\section{APPENDIX D:}

\section{SURVEYING POTENTIAL ATTENDEES}

\section{D.1 DATA COLLECTION}

Knowledge about potential attendees is important when planning for public participation activities. It can be helpful to know what participants may be like and how participation efforts can be structured so that the interaction benefits both the agency and participants. To obtain information from this group, approximately 2,800 questionnaires were sent to people who had attended the 23 scoping meetings for the programmatic environmental impact statement (PEIS); they were considered most likely to attend meetings or workshops on the implementation plan (IP) for the PEIS. The questionnaire is included as Figure D.1. (All figures in this appendix are included after Section D.3.)

Questions on the mailout questionnaire solicited information on whether potential attendees would actually be attending a meeting, preferences for types of meeting, value of premeeting material, and factors the public considered necessary for providing input to the U.S. Department of Energy (DOE). Approximately 188 of these questionnaires were returned. The low response rate $(7 \%)$ requires cautious interpretation of the data; for this reason, the results were not included in the main body of this report. In terms of potential attendance at the workshops, several respondents indicated they would not attend because the locations were inconvenient and travel was too expensive.

\section{D.2 RESULTS}

Potential attendees were sent several documents to help them prepare for the IP meetings, including a summary of the IP and a set of fact sheets. They were asked their level of involvement with the material, such as whether they read the material or asked for more information. For the most part, respondents were moderately involved with the material (Figure D.2). More than three-quarters of respondents skimmed the material or read some of it; more than half of respondents indicated they read all the material. Furthermore, more than two-thirds of respondents indicated they gave their material to someone else. Respondents were, however, less likely to be involved in actually doing something with their comments. Less than $40 \%$ indicated that they would send in their comments, and about $80 \%$ said they would not ask for more information.

It is important to understand what respondents did with the information they received; moreover, it is also necessary to know what they thought of the information in terms of its relevance for their needs. Respondents who were potential attendees were asked to rate the premeeting materials they received in terms of understandability, accuracy, appropriateness of level of detail, and ability to hold the reader's interest. Respondents felt the information was generally effective in terms of these four criteria (Figure D.3). 
Potential attendees also were requested to indicate how they would like to provide input to DOE (Figure D.4). The most preferred method for providing input to DOE was an open public forum; the next choice was informal workshops. The least preferred method for providing input was a public meeting.

In addition, potential attendees were asked about the resources necessary for providing input to DOE within the National Environmental Policy Act (NEPA) process (Figure D.5). Respondents were particularly interested in having conveniently located meetings and being notified early in the process about upcoming public involvement opportunities. They were also interested in having information on specific issues and on how they might participate. Potential attendees were least interested in receiving personalized attention and information on the NEPA process itself.

\section{D.3 SUMMARY OF RESULTS AND SUGGESTIONS}

Although respondents looked at the material they received in their mailout packet and felt it was understandable and interesting, they did not appear to examine it closely in terms of reading it all or following up by providing input to DOE. This suggests that extra effort may be necessary on DOE's part to solicit comments from potential participants, as they are not likely to provide input without encouragement.

Although DOE often uses public meetings as a method for soliciting public input, this approach was seen as the least desirable by those who might attend a meeting. Rather, potential attendees preferred informal meetings and open public forums. These formats should be coupled with conveniently located sessions. The public should be informed well in advance and should receive information on specific issues and how members of the public can participate in the process. The IP public workshops were seen by respondents at the meetings as a first step in this direction. 


\section{Environmental Restoration and Waste Management Mail Survey}

Please return this survey as soon as possible with the provided, postage-paid envelope.

Thank you for your help.

Do you plan to attend the public meeting at one of the following locations?

(Please check the appropriate location.)

Atlanta, Georgia

Washington, D.C. Spokane, Washington
Las Vegas, Nevada

Denver, Colorado

If you are not planning attend, please list the reason(s) why.

In regard to the premeeting material accompanying this questionnaire, did you:

$\begin{array}{ll}\text { Yes } & \text { No }\end{array} \quad \begin{aligned} & \text { Skim material } \\ & \text { Read some of the information } \\ & \text { Read all the information } \\ & \text { Send in written comments } \\ & \text { Ask for more information } \\ & \text { Give to colleague } \\ & \text { Throw information out }\end{aligned}$

Circle your rating of the premeeting material on the following dimensions:

Accuracy

Understandability

Appropriateness of level of detail

Ability to hold your interest

$\begin{array}{ccccc}\text { none } & \text { low } & \text { some } & \text { moderate } & \text { high } \\ 1 & 2 & 3 & 4 & 5 \\ 1 & 2 & 3 & 4 & 5 \\ 1 & 2 & 3 & 4 & 5 \\ 1 & 2 & 3 & 4 & 5\end{array}$

Circle your preference for the following approaches to providing input to DOE:

$\begin{array}{llcccc} & \text { no } & \text { weak } & \text { some } & \text { moderate } & \text { strong } \\ \text { Public meeting with DOE presentation (no Q\&A session) } & 1 & 2 & 3 & 4 & 5 \\ \text { Informal small group workshops } & 1 & 2 & 3 & 4 & 5 \\ \text { Letter writing } & 1 & 2 & 3 & 4 & 5 \\ \text { Open public forum (open Q\&A session) } & 1 & 2 & 3 & 4 & 5 \\ \text { Direct mail requests for input } & 1 & 2 & 3 & 4 & 5 \\ \text { Other (please specify } & 1 & 2 & 3 & 4 & 5\end{array}$

FIGURE D.1 Mailout Questionnaire 
Please circle how important the following factors are in your ability to provide input to DOE in the NEPA process:

not at all a little somewhat moderately extremely

Information on how to participate

Personalized attention

Written material on the National

Environmental Policy Act

Written material on DOE facilities

Early notice of events

Information in the news media

Explanations of terms and abbreviations

Convenience of meeting locations

Regular meetings with DOE

Choice of times for meetings

Information on specific issues
1

1

1

1

1

1

1

1

1

1

1

\section{2}

2

2

2

2

2

2
2

2
2

2

3

3

3

3

\section{3}

3
3

3
3

$\begin{array}{ll}2 & 3 \\ 2 & 3 \\ 2 & 3 \\ 2 & 3\end{array}$

4
4
4

5

5

5

Do you wish to remain on the mailing list for PEIS materials?

$\begin{array}{ll}4 & 5 \\ 4 & 5 \\ 4 & 5 \\ 4 & 5\end{array}$

$\begin{array}{ll}4 & 5 \\ 4 & 5 \\ 4 & 5 \\ 4 & 5\end{array}$

Which of the following documents would you like to receive?

_ Executive Summary of the Programmatic Environmental Impact Statement (PEIS) Volume 1

- Draft PEIS

— DRAFT PEIS plus Appendices

_ Final PEIS

_ Final PEIS plus Appendices

To ensure that your request is honored, please provide your name and address below:

Name

Address

City, State, Zip Code

Additional Comments (if more space is needed, use back of page 1).

FIGURE D.1 (Cont.) 


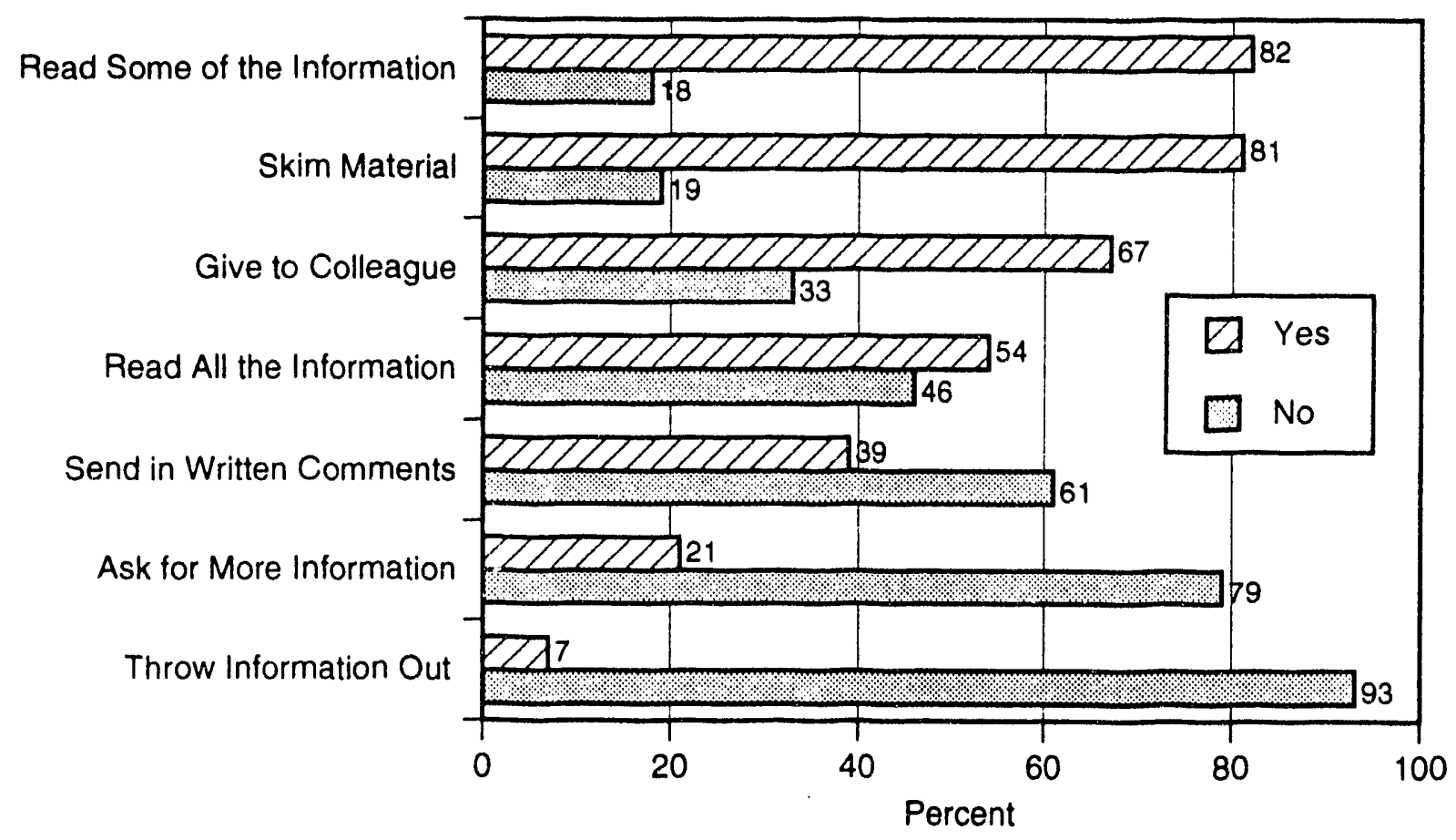

FIGURE D.2 Potential Attendees' Involvement with Premeeting Material Accompanying the Mailout Questionnaire

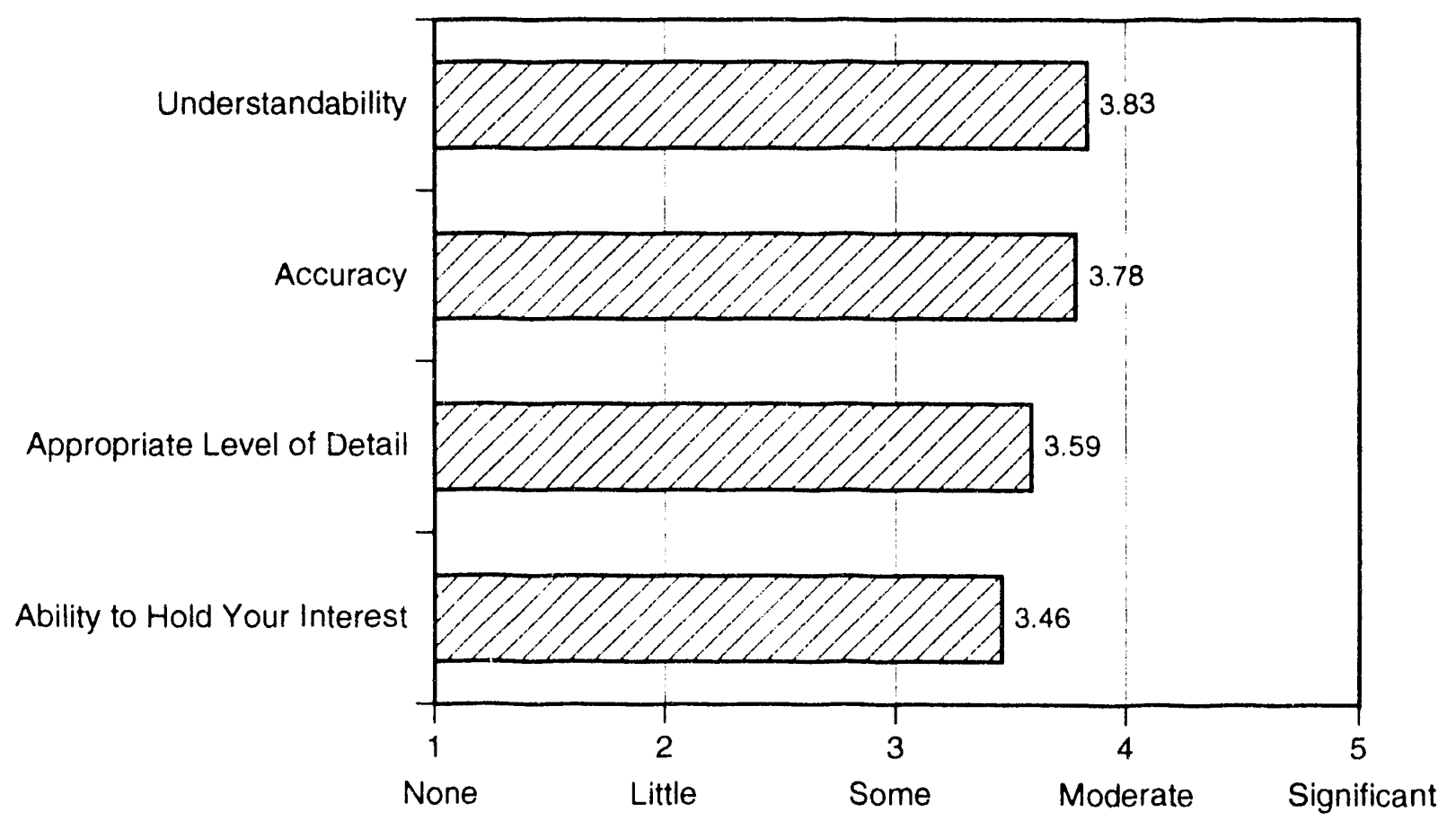

FIGURE D.3 Potential Attendees' Perspectives on the Premeeting Materials 


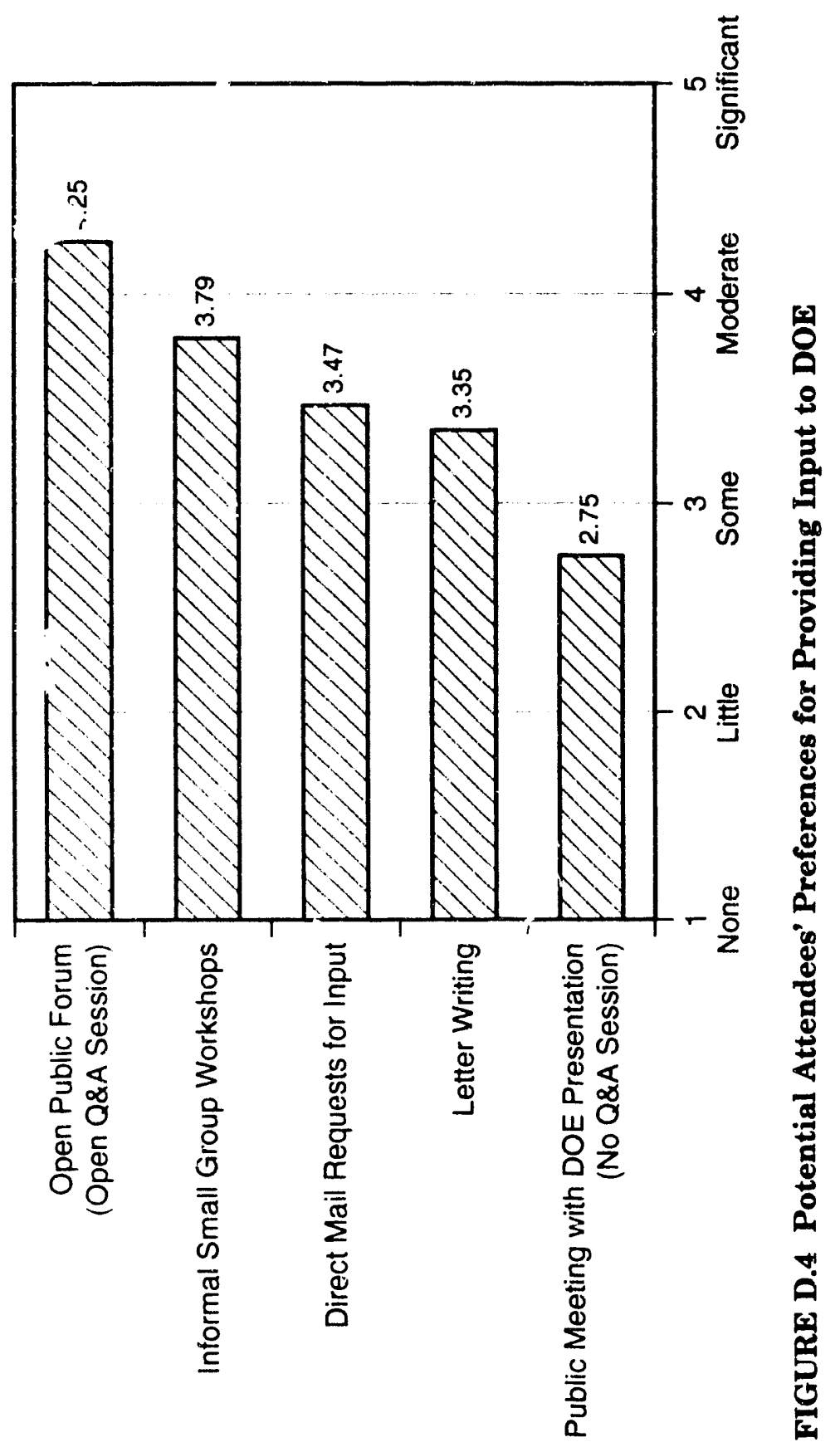




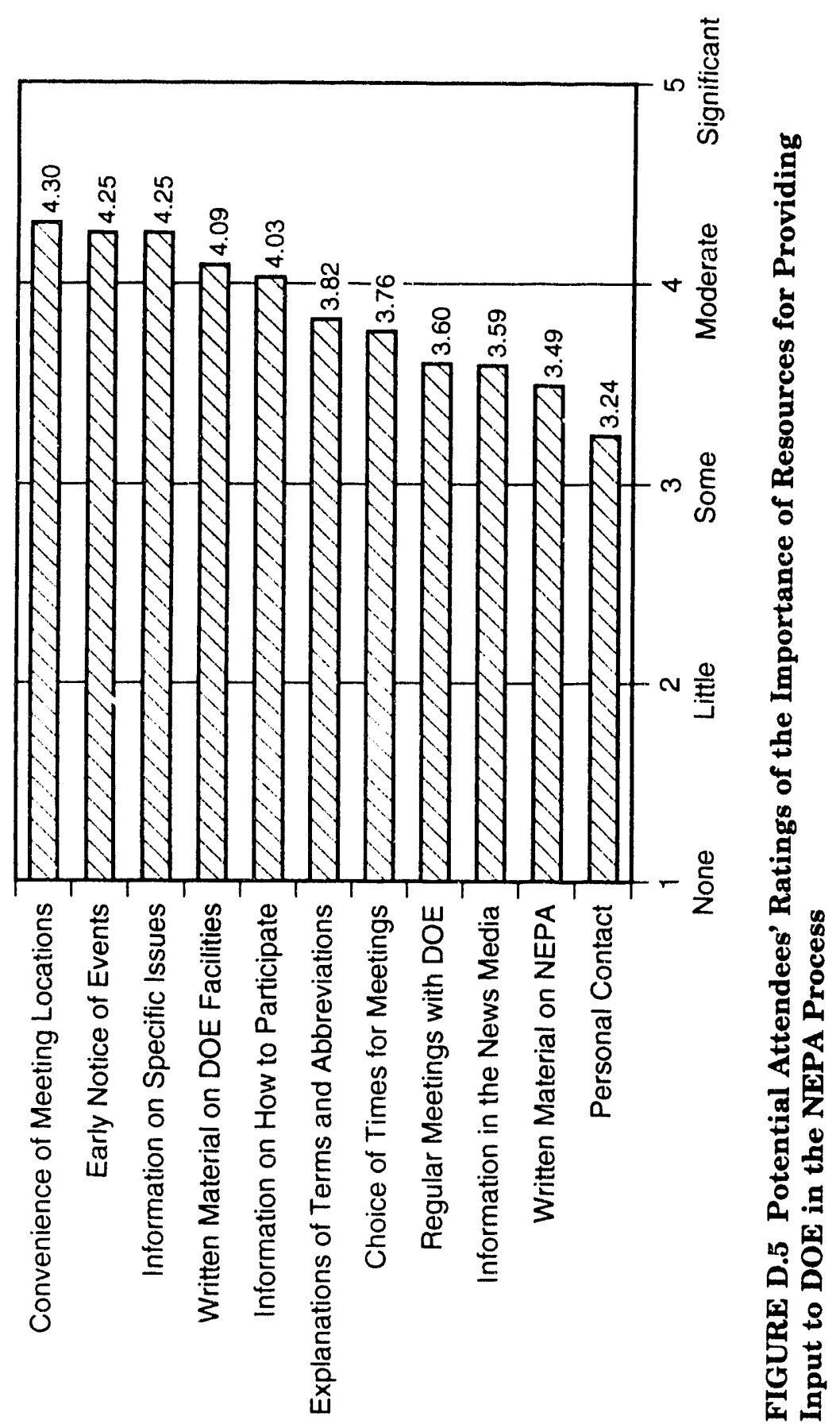





I




